Review

\title{
Role of Chemokines in Non-Small Cell Lung Cancer: Angiogenesis and Inflammation
}

\author{
Selma Rivas-Fuentes ${ }^{\circledR}$, Alfonso Salgado-Aguayo ${ }^{2}$, Silvana Pertuz Belloso ${ }^{3}$, Patricia Gorocica Rosete ${ }^{1}$, Noé \\ Alvarado-Vásquez ${ }^{1}$, Guillermo Aquino-Jarquin ${ }^{4}$ \\ 1. Department of Biochemistry Research, National Institute of Respiratory Diseases "Ismael Cosío Villegas", Mexico City, Mexico. \\ 2. Laboratory of Research on Rheumatic Diseases, National Institute of Respiratory Diseases "Ismael Cosío Villegas", Mexico City, Mexico. \\ 3. Department of Comparative Biology, Faculty of Sciences, National Autonomous University of Mexico, Mexico City, Mexico. \\ 4. Laboratory of Research on Genomics, Genetics and Bioinformatics. Tower of Haemato-oncology, Children's Hospital of Mexico "Federico Gomez", Mexico \\ City, Mexico. \\ $\triangle$ Corresponding author: Department of Biochemistry Research, National Institute of Respiratory Diseases "Ismael Cosío Villegas", Mexico City, Mexico. \\ Calzada de Tlalpan 4502, Tlalpan, Ciudad de México, D.F. 14080, México. Phone +52 (55) 5487 1705; E-mail: selma.rivas@iner.gob.mx.
}

() 2015 Ivyspring International Publisher. Reproduction is permitted for personal, noncommercial use, provided that the article is in whole, unmodified, and properly cited. See http:/ /ivyspring.com/terms for terms and conditions.

Received: 2015.03.30; Accepted: 2015.06.23; Published: 2015.08.07

\begin{abstract}
Non-small cell lung cancer (NSCLC) is one of the most common types of aggressive cancer. The tumor tissue, which shows an active angiogenesis, is composed of neoplastic and stromal cells, and an abundant inflammatory infiltrate. Angiogenesis is important to support tumor growth, while infiltrating cells contribute to the tumor microenvironment through the secretion of growth factors, cytokines and chemokines, important molecules in the progression of the disease. Chemokines are important in development, activation of the immune response, and physiological angiogenesis. Chemokines have emerged as important regulators in the pathophysiology of cancer. These molecules are involved in the angiogenesis/angiostasis balance and in the recruitment of tumor infiltrating hematopoietic cells. In addition, chemokines promote tumor cell survival, as well as the directing and establishment of tumor cells to metastasis sites. The findings summarized here emphasize the central role of chemokines as modulators of tumor angiogenesis and their potential role as therapeutic targets in the inflammatory process of NSCLC angiogenesis.
\end{abstract}

Key words: Chemokines, cytokines, angiogenesis, inflammation, non-small cell lung cancer.

\section{Introduction}

Lung cancer is the main cancer-related cause of death worldwide in both men and women [1]. It is classified into two types according to the size of the transformed cells: small-cell lung cancer (SCLC) and non-small cell lung cancer (NSCLC). The latter is the most common type, accounting for 85 to $90 \%$ of diagnosed cases, and although NSCLC spreads more slowly than SCLC, both have a poor prognosis [2].

NSCLC is a cancer of epithelial origin that groups together various histological subtypes that differ in their cytology, embryonic origin, anatomical location, and associated oncogenes [3]. The most common subtypes of NSCLC are adenocarcinoma ( $40 \%$ of all forms of lung cancer), squamous-cell carcinoma (25-to $30 \%$ ) and large-cell carcinoma (10 to
$15 \%)$ [2].

In NSCLC, the tumor stroma is characterized by active angiogenesis and abundant inflammatory infiltrate, which is mainly composed of tumor-associated macrophages (TAM). It is also characterized by the presence of tumor-infiltrating lymphocytes (TIL), including T, B and NK cells, and tumor-associated neutrophils (TAN) [4, 5]. The differences in the inflammatory infiltrate are attributable to the local production of chemokines, which are also important regulators of the angiogenesis that accompanies tumor growth [6].

\section{Chemokines}

Chemokines are a family of soluble proteins that 
direct the migration of leukocytes under physiological conditions and during inflammation [7]. They are important in embryonic development, activation of the immune response, and in driving both physiological and pathological angiogenesis. Chemokines exert their biological effects on leukocytes through the activation of seven transmembrane domain receptors coupled to heterotrimeric $G$ proteins [8]. The activation of the classical chemokine receptors initiates protein phosphorylation events, including PI3K, and the generation of second messengers such as IP3 and DAG, along with increased intracellular calcium concentration $\left(\left[\mathrm{Ca}^{2+}\right]_{\mathrm{i}}\right)$ and activation of transcription factors such as NF- $\kappa \mathrm{B}$, which regulates the expression of various inflammatory response-related genes [8-10]. About fifty chemokines and twenty chemokine receptors are currently known [11]. Some chemokines can bind with high affinity to more than one receptor, and some receptors can be activated by more than one chemokine [12] (Table 1). The biological significance of this promiscuity of ligands and receptors may be related to the diversity of functions of these proteins [13]. Furthermore, some chemokine receptors have been described that, after binding to ligands, do not contribute to cell migration or to cell functions related to cell activation; these receptors are called atypical receptors, and are negative regulators of the activity of chemokines [14, 15]. Atypical chemoattractant receptors (Table 1), such as ACKR1 (DARC), ACKR2 (D6), ACKR3 (CXCR7) and ACKR4 (CCRL1), limit the amount of available ligands in the microenvironment due to their ability to internalize and degrade them; for this reason they are also known as "decoy receptors" [14, 15]. Chemokines are currently classified according to a systematic nomenclature based on the position of the cysteines located nearest to the $\mathrm{N}$-terminal end of the protein. These are usually two cysteines that are together, or separated by 1 or 3 amino acid residues $(X)$. Four types of arrangements of cysteines have been described so far, according to which chemokines are divided into four sub-families:
CC, $\mathrm{CXC}, \mathrm{CX}_{3} \mathrm{C}$ and $\mathrm{XC}$ [16]. The CXC subfamily is divided into two groups, CXC $\left(\mathrm{ELR}^{+}\right)$and CXC (ELR-), according to the presence or absence of the amino acid motif consisting of glutamic acid, leucine and arginine (ELR motif) $[7,16]$.

Chemokines and their receptors are expressed in immune system cells, endothelial and epithelial cells, fibroblasts and keratinocytes, among others [17]. Some chemokines and their receptors have a constitutive expression, while others are affected by changes in the cellular microenvironment and therefore are categorized as inducible [18]. For example, stimulation with tumor necrosis factor (TNF- $\alpha$ ) increases the expression of the chemokine CCL5 and its receptor CCR5 in the central nervous system [15], whilst interferon gamma (INF- $\gamma$ ) is a potent inducer of the expression of CXC-ELR- chemokines [19-21].

\section{Chemokines and their receptors in the cancer process.}

For the past 20 years, there have been studies aimed at understanding the role of chemokines in the pathophysiology of cancer. It is currently accepted that the system of chemokines and their receptors has direct and indirect effects on the pathophysiology of cancer and that these molecules are important in the development and progression of the disease. Chemokines and their receptors are regulators of angiogenesis, which allows tumor growth and metastasis [22]. Furthermore, chemokines and their receptors mediate the recruitment of cells of the immune system to the tumor microenvironment. These cells actively modify the microenvironment; for example, macrophages are recruited by a pro-inflammatory environment and contribute to perpetuate inflammation through the production of angiogenic factors such as VEGF-A [23]. Finally, it has been shown that chemokines induce the proliferation of cancer cells and promote the metastasis of tumor cells by inducing a more motile phenotype $[24,25]$.

Table 1. Complexity of the ligand-receptor system in the chemokine family. There are 4 subfamilies of chemokines, classified according to the position of the $\mathrm{N}$-terminal cystein residues: CC, CXC, CX3C and XC. The chemokine-chemokine receptor system is quite complex, since some chemokines can activate several receptors, and a single receptor can have several ligands (bold text). To date, 5 atypical receptors have been characterized, which do not induce activation after ligand binding (last column).

\begin{tabular}{|c|c|c|c|c|}
\hline $\mathrm{CC}$ & CXC & $\mathrm{CX} 3 \mathrm{C}$ & $\mathrm{XC}$ & ATYPICAL CHEMOKINE RECEPTOR \\
\hline CCR1 (CCL3,5,7,8,14,15,16, 23) & CXCR1 (CXCL1,6,7,8) & CX3CR1 (CX3CL1) & XCR1(XCL1,2) & ACKR1 \\
\hline CCR2 (CCL2,7,8,12,13) & CXCR2(CXCL1,2,3,5,6,7,8) & & & ACKR2 \\
\hline CCR3 (CCL5,7,8,11,13,15,24,26) & CXCR3 (CXCL4, CXCL4L1, CXCL9,10,11) & & & ACKR3 \\
\hline CCR4 $($ CCL17,22) & CXCR4 (CXCL12) & & & ACKR4 \\
\hline CCR5 (CCL3,4,5) & CXCR5 (CXCL13) & & & ACKR5 \\
\hline CCR6 (CCL20) & CXCR6 (CXCL16) & & & \\
\hline CCR7 (CCL19,21) & CXCR7 (CXCL12) & & & \\
\hline \multicolumn{5}{|l|}{ CCR8 (CCL1,4,17) } \\
\hline \multicolumn{5}{|l|}{ CCR9 (CCL25) } \\
\hline \multicolumn{5}{|l|}{ CCR10 (CCL27, 28) } \\
\hline CCR11 (CCL8,13) & & & & \\
\hline
\end{tabular}




\section{Angiogenesis, chemokines and cancer}

Angiogenesis is a key process in cancer development. It is a multi-step process coordinated by several types of molecules (including the chemokines), most of them soluble and secreted by immune, stromal and neoplastic cells, as well as by activated endothelium [26]. In the adult, physiological angiogenesis is involved in wound repair and formation of the endometrium [26, 27]. Aberrant angiogenesis occurs in cancer as a result of alterations in the expression of molecules controlling the process, such as the chemokines [28-30]. At the cellular level, angiogenesis is a complex process involving several stages. It begins with the activation of endothelial cells and the destabilization of capillary structures. Activated endothelial cells produce matrix metalloproteinases (MMPs); initiate cell proliferation programs and acquire migratory properties [28, 30]. Angiogenesis is coordinated by many types of molecules, which together are called angiogenic and angiostatic factors, according to whether they promote or inhibit angiogenesis [31-33].
CXC chemokines have a dual role in angiogenesis, since some members of this subfamily are angiogenic and others are angiostatic [34, 35] (Table 2). In 1995, Strieter et al showed that CXC-ELR ${ }^{+}$chemokines have angiogenic properties, can induce in vitro the chemotaxis of endothelial cells, and neovascularization in the rat cornea model; while CXC-ELR- chemokines have angiostatic properties, and inhibit neovascularization even in the presence of angiogenic chemokines and FGF-2[34, 36]. Furthermore, the use of chemokines with mutations on the ELR motif, or the addition of an ELR sequence to CXC-ELR- chemokines, showed that the ELR motif is central to the angiogenic/angiostatic activity of CXC chemokines [36]. The only known exception is CXCL12, which lacks the ELR motif but has angiogenic activity mediated through its receptors CXCR4 and CXCR7 [37, 38] (Table 3). The expression of CXC-ELR- chemokines is finely regulated by INF- $\gamma$, produced mainly by lymphoid cells during both innate and adaptive immune responses [26].

Table 2. Major angiogenic and angiostatic molecules. The table shows the major angiogenic and angiostatic molecules and their receptors, and their participation in the angiogenic process. One of the most important angiogenic factors are VEGF-A, FGF-2, Ang-2, MMP2 \& MMP9, TNF- $\alpha$, TGF- $\beta$, and the CXC-ELR ${ }^{+}$chemokines. On the other hand, the major angiostatic factors are IFN- $\gamma$, Angiostatin, Thrombospondin-2, TIMP, (mainly TIMP-2 and TIMP-3), and the CXC-ELR' chemokines.

\begin{tabular}{|c|c|c|c|}
\hline TYPE OF MOLECULES & MOLECULES & RECEPTOR & FUNCTION \\
\hline \multicolumn{4}{|l|}{ ANGIOGENIC MOLECULES } \\
\hline VEGF Family & VEGF-A & $\begin{array}{l}\text { VEGFR-1 } \\
\text { VEGFR-2 }\end{array}$ & $\begin{array}{l}\uparrow \text { Proliferation (EC, P) } \\
\uparrow \text { Migration (EC) } \\
\uparrow \text { Formation of tubular structures }\end{array}$ \\
\hline FGF Family & FGF-2 & $\begin{array}{l}\text { FGFR-1 } \\
\text { FGFR-2 } \\
\text { FGFR-3 } \\
\text { FGFR-4 }\end{array}$ & $\begin{array}{l}\uparrow \text { Proliferación (EC, F) } \\
\uparrow \text { Migration (EC) } \\
\uparrow \text { VEGF Expression } \\
\uparrow \text { Formation of capillary structure } \\
\uparrow \text { Inflammation- related genes }\end{array}$ \\
\hline Angiopoietin (Ang) & $\begin{array}{l}\text { Ang-1* } \\
\text { Ang-2 }\end{array}$ & $\begin{array}{l}\text { Tie-1 } \\
\text { Tie-2 }\end{array}$ & $\begin{array}{l}\uparrow \text { Sprouting*, proliferation, migration, vessel stabilization* (EC) } \\
\uparrow \text { Recruitment and activation of mural cells }\end{array}$ \\
\hline Metalloproteinases (MMP) & $\begin{array}{l}\text { MMP-2 } \\
\text { MMP-9 }\end{array}$ & $\begin{array}{l}\text { None } \\
\text { Substrate: } \\
\text { Basement } \\
\text { Membrane (BM) } \\
\text { Extracellular Matrix } \\
\text { (ECM) }\end{array}$ & $\begin{array}{l}\uparrow \text { Degradation of BM and ECM } \\
\uparrow \text { Migration (EC) }\end{array}$ \\
\hline Cytokines & $\begin{array}{l}\text { TNF- } \alpha \\
\text { TGF- } \beta\end{array}$ & $\begin{array}{l}\text { TNFR } \\
\text { T } \beta R I \\
\text { T } \beta R I I\end{array}$ & $\begin{array}{l}\uparrow \text { Migration (EC) } \\
\uparrow \text { Tube formation } \\
\uparrow \text { Vessel stabilization } \\
\uparrow \text { Inflammation } \\
\uparrow \text { Tube formation }\end{array}$ \\
\hline CXC Chemokines & CXC-ELR ${ }^{+}$ & $\begin{array}{l}\text { CXCR2 } \\
\text { CXCR4 } \\
\text { CXCR7 }\end{array}$ & $\begin{array}{l}\uparrow \text { Proliferation, migration, inflammation (EC) } \\
\uparrow \text { Secretion and activation of MMPs }\end{array}$ \\
\hline Transcription factors & $\begin{array}{l}\text { HIF-1a* } \\
\text { NF-kB** } \\
\text { AP-1*** }\end{array}$ & & $\begin{array}{l}\uparrow^{*} \text { Expression of VEGF, VEGFR, CXCL8 } \\
\uparrow \mathrm{bFGF} \\
\uparrow^{* *} \text { Expression of CXCR2, CCL5, CXCL8 } \\
\uparrow^{* * *} \text { CXCL8 }\end{array}$ \\
\hline $\begin{array}{l}\text { ANGIOSTATIC MOLECUL } \\
\text { Angiostatin }\end{array}$ & -- & None. & $\downarrow$ Proliferación (EC) \\
\hline
\end{tabular}




\begin{tabular}{|c|c|c|c|}
\hline & & $\begin{array}{l}\text { Angiosotatin binds several } \\
\text { proteins: } \\
\text { Angiomotin } \\
\text { ATP synthase } \\
\text { Integrins } \\
\text { Annexin II } \\
\text { NG2 proteoglycan }\end{array}$ & $\begin{array}{l}\downarrow \text { Migration (EC) } \\
\downarrow \text { Formation of capillary structure } \\
\downarrow \text { VEGF Expression }\end{array}$ \\
\hline Endostatin & -- & $\begin{array}{l}\text { None } \\
\text { Endostatin binds several } \\
\text { proteins }\end{array}$ & $\begin{array}{l}\downarrow \text { Proliferación (EC) } \\
\uparrow \text { Apoptosis } \\
\downarrow \text { Migration (EC) } \\
\text { Inhibition MMPs Acivation } \\
\downarrow \text { VEGF Expression }\end{array}$ \\
\hline CXC Chemokines & CXC-ELR- & CXCR3B & $\begin{array}{l}\downarrow \text { Migratory form } \\
\downarrow \text { Proliferation } \\
\downarrow \text { Formation of capillary structures }\end{array}$ \\
\hline Cytokines & INF- $\gamma$ & $\begin{array}{l}\text { INFgammaRI } \\
\text { INFgammaRII }\end{array}$ & $\begin{array}{l}\uparrow * \text { Expression of angiostatic chemokines } \\
\downarrow \text { Angiogenesis }\end{array}$ \\
\hline MMPs Inhibitors: TIMP & $\begin{array}{l}\text { TIMP-2 } \\
\text { TIMP-3 }\end{array}$ & Inhibition of MMPs & $\begin{array}{l}\downarrow \text { Migratory form } \\
\downarrow \text { Proliferation } \\
\downarrow \text { Formation of capillary structures }\end{array}$ \\
\hline
\end{tabular}

Abbreviations: AP-1, Activator Protein 1;BM, Basement Membrane; EC, Endothelial Cells; EpC Ephitelial Cells, ECM, Extracellular Matrix; FGF, Fibroblast Growth Factor; F,

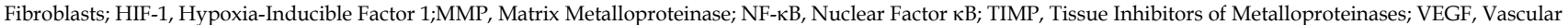
Endothelial Growth Factor.

Table 3. Chemokines and chemokine receptors involved in angiogenesis and associated inflammation. The main chemokines and chemokine receptors that play a dual role in angiogenesis and the recruitment of immune cells into tissues were classified according to the major receptors, cellular source and target cells.

\begin{tabular}{|c|c|c|c|c|c|c|}
\hline Sub- Family & Systematic Name & Classic Name & Major Receptors & Cell Source & Target Cell & Effect \\
\hline CXC & CXCL1 & Gro- $\alpha$ & CXCR1, CXCR2 & $\mathrm{Ne}, \mathrm{Ma}, \mathrm{EpC}$ & $\mathrm{Ne}, \mathrm{Mo}, \mathrm{EC}$ & Angiogenic \\
\hline \multirow[t]{6}{*}{ ELR+ } & CXCL2 & Gro- $\beta$ & CXCR2 & $\mathrm{Ne}, \mathrm{Ma}$ & $\mathrm{NK}, \mathrm{Mo}, \mathrm{DC}, \mathrm{Ba}, \mathrm{T}$ & \\
\hline & CXCL3 & Gro- $\gamma$ & CXCR2 & $\mathrm{Ne}, \mathrm{EpC}, \mathrm{Ma}$ & EpC & \\
\hline & CXCL5 & ENA-78 & CXCR2 & $\mathrm{Ne}$ & & \\
\hline & CXCL6 & GCP-2 & CXCR1, CXCR2 & $\mathrm{Ne}, \mathrm{Ma}$ & & \\
\hline & CXCL7 & NAP-2 & CXCR1, CXCR2 & $\mathrm{Ne}, \mathrm{Ma}$ & & \\
\hline & CXCL8 & IL-8 & CXCR1, CXCR2 & $\mathrm{Ne}, \mathrm{Ma}, \mathrm{T}, \mathrm{EC}, \mathrm{EpC}, \mathrm{T}, \mathrm{F}$ & & \\
\hline CXC & CXCL4 & PF4 & CXCR3A, CXCR3B & $\mathrm{P}$ & $\mathrm{F}, \mathrm{Ne}, \mathrm{Mo}$ & Angiostatic \\
\hline \multirow[t]{6}{*}{ ELR- } & CXCL4L1 & PF4alt & CXCR3A, CXCR3B & $\mathrm{EC}$ & $\mathrm{F}, \mathrm{Ne}, \mathrm{Mo}$ & \\
\hline & CXCL9 & MIG & CXCR3A, CXCR3B & EC, Th1, NK & Th1, NK & \\
\hline & CXCL10 & IP-10 & CXCR3A, CXCR3B & EC, Th1, NK, Mo, F & Th1, NK & \\
\hline & CXCL11 & I-TAC & CXCR3A, CXCR3B & Th1, NK & Th1, NK & \\
\hline & CXCL14 & BRAK & Unknown & & Mo, Ma, iDC, NK & \\
\hline & CXCL12 & SDF-1 & CXCR4, CXCR7 & & Leukocytes & Angiogenic \\
\hline \multirow[t]{2}{*}{$\mathrm{CC}$} & CCL2 & MCP-1 & $\mathrm{CCR} 2,4$ & $\mathrm{Mo}, \mathrm{Ma}, \mathrm{T}, \mathrm{NK}, \mathrm{iDC}, \mathrm{B}, \mathrm{Ba}, \mathrm{EpC}$ & Mo, Ma, T, NK, iDC, B, Ba, Ne & Angiogenic \\
\hline & CCL5 & RANTES & CCR5,1,3, 4 & EC, Mo, Ma, T, NK, iDC, Ba, Eo & EC, Mo, Ma, T, NK, iDC, Ba, Eo & \\
\hline
\end{tabular}

In some diseases such as cancer, hypoxic conditions can alter angiogenesis, since the expression of several angiogenic molecules, including VEGF, VEGFR and the chemokine CXCL8, are under transcriptional regulation of Hypoxia Inducible Factor (HIF-1) [30, 39], which, as its name suggests, activates the transcription of various genes in response to low oxygen levels. In addition, there are reports that HIF-1 can be activated independently of hypoxia; this activation is related to the expression of oncogenes, growth factors and chemokines [40,41].

In the neoplastic process, alterations in angiogenesis have important implications. It has been shown that the growth of tumors larger than 2-3 $\mathrm{mm}^{3}$ is dependent on angiogenesis [42]. In addition, angiogenesis facilitates the invasion of malignant cells into the circulation and is also important in the establishment of these cells at the site of metastasis $[22,29,43]$.

In turn, chemokines regulate and are also regulated by other angiogenic factors. For example, the metastatic potential of some tumors correlates with the expression levels of some MMPs [44], and CXCL8 induces the secretion and activation of MMP-2 in endothelial cells $[45,46]$. Furthermore, CCL7 is cleaved by MMP-2, and thus loses the capacity to induce chemotaxis and calcium fluxes, but retains its ability 
to bind to CCR1, CCR2 and CCR4 receptors. Thus, CCL7, digested by MMP-2, acts as a chemokine antagonist $[47,48]$. In short, the relationship between chemokines and MMPs may have important implications in the development of angiogenesis and inflammation, and have an indirect impact on the evolution of the neoplastic process [45].

\section{Inflammation, chemokines and cancer}

The composition of cell subpopulations in the tumor microenvironment is important for the evolution of the neoplastic process. The tumor tissue is composed of tumor cells, stromal cells and infiltrating leukocytes [49]. These cells secrete chemokines that orchestrate the recruitment of cells of the immune system to the tumor microenvironment. In prostate cancer, CCL2 is important for infiltration of TAM into the neoplastic tissue [50]. These cells have high plasticity and are often polarized in the tumor towards a phenotype known as M2, which favors angiogenesis, because it is associated with the secretion of TGF- $\beta$, FGF, VEGF and CXC-ELR ${ }^{+}$chemokines [51]. In addition, TAM M2 produces IL-10, a cytokine that represses the cytotoxic immune response and can contribute to tumor escape mechanisms [51, 52]. TAM produce the CXCL1, CXCL3, CXCL5, and CXCL8 chemokines, which are chemoattractant for neutrophils and could be responsible for the infiltration of TAN; meanwhile CXCL17 is a chemoattractant for immature myeloid cells and macrophages $[53,54]$.

Although it is not clear yet how important is the infiltration of TAN for the prognosis of the neoplastic process $[5,55]$, it is known that some of the compounds released by neutrophils, such as hypochlorous acid $(\mathrm{HOCl})$, are genotoxic[56]. In vitro tests have shown that $\mathrm{HOCl}$ is mutagenic in lung adenocarcinoma cells A549 [56]. In addition, the local production of $\mathrm{HOCl}$ actives MMP- 2, 7, 8 and 9, and inactivates the metalloprotease inhibitor TIMP-1, which may favor the invasion process $[57,58]$.

Another cell type that is frequently found in the transformed tissue is composed by regulatory $\mathrm{T}$ cells, which are increased in several types of cancer, including esophageal squamous cell carcinoma and gastric cancer [59-61]. In the murine model of Lewis lung carcinoma, CCL22 was identified as a chemokine involved in the recruitment of regulatory $\mathrm{T}$ cells; this chemokine is produced by NK cells and TAM [62].

\section{Chemokines in non-small cell lung cancer}

In the last decade, several clinicopathological studies have focused on establishing whether there are associations between the expression level of chemokines and/or their receptors in tumor tissue, patient survival or development of NSCLC. In this regard, it has been reported that the increased expression of the chemokine CCL5 in grade I lung adenocarcinoma correlates with an increase in the survival rate [63], but, as will be discussed later, these results are controversial. On the other hand, the high expression of CXCL8 is related to a worse outcome of the disease [64]. In the studies mentioned above, the pro-angiogenic effect of CXCL8 could stimulate the neoplastic process through increased tumor cell survival and tumor growth, while the higher expression of CCL5 could be related to a more efficient anti-tumor response through an augmented recruitment of T lymphocytes [65]. There seems to be significant differences in the expression of chemokine receptors in the stromal region and in the tumor foci of neoplastic tissue. Ohri and colleagues analyzed the expression of CXCR2-5 and CCR1 receptors, and their correlation with the survival, in a cohort of 20 patients with NSCLC (mainly squamous cell carcinoma). The increased expression of CXCR2, CXCR3 and CCR1 in the foci of tumor cells was associated with greater survival, while the increased expression in stromal cells of CXCR2, CXCR3 and CXCR4 was associated with a lower survival [66]. Further studies are needed to understand the significance of this phenomenon.

\section{Relevant CC chemokines in NSCLC CCL2}

The CCL2/CCR2 axis is important in several aspects of tumorigenesis and one of the most relevant is the generation of new vascular structures that allow tumor growth [67]. Treatment with CCL2-neutralizing antibodies showed that this chemokine is important in tumor vascularization and growth [68]. At least two mechanisms are involved in angiogenesis mediated by CCL2. First, CCL2 directly activates endothelial cells and induces their migration and the formation of capillary structures [68, 69]. Second, CCL2 indirectly promotes angiogenesis by recruiting TAM precursor cells (which are a major source of angiogenic molecules) and/or influencing their polarization [50, 70]. In NSCLC, the chemokine CCL2 is expressed by tumor and stromal cells [71, 72]. It has been demonstrated that tumor tissue homogenates are monocyte chemoattractant, and that the use of neutralizing antibodies against CCL2 significantly reduces this effect [71]. These results strongly suggest that CCL2 is crucial in the infiltration of monocytes, which are TAM precursor cells. However, in vivo murine models of tumorigenesis showed that the neutralization of CCL2 did not alter the number of TAM, although it promoted the polarization of TAM towards the M1 phenotype (associated with an an- 
ti-tumor response mediated by CD8+T cells)[73], while the presence of CCL2 favored the polarization towards the M2 phenotype, which produces angiogenic molecules. In addition, CCL2 induces the recruitment of myeloid suppressor cells (MDSC) [74], which are associated with tumor progression and promotion due to their immunosuppressive activities and are also a source of angiogenic factors. Furthermore, it has been reported that the recruitment of these cells through CCL2/CCR2, is important in the metastasis of colorectal cancer [75]. It is also known that in breast and prostate cancer, the CCL2/CCR2 axis mediates metastasis to bone and lung tissue [76]. In addition, the use of CCL2 $\%$ mice in a model of breast cancer (4T1 cell line) showed that stromal CCL2 favors metastasis of transformed cells to the lung [72]. Although in vitro studies and humanized animal models indicate that the presence of CCL2 favors the progression of the neoplastic process, a recent clinicopathological study of 65 patients with advanced NSCLC concluded that the expression of CCL2 in tumor tissue is related to greater survival [77].

\section{CCL5}

This chemokine is an important biomarker due to its ability to distinguish patients with NSCLC from healthy controls when measured in serum [78]. The role of this chemokine in tumor progression is unclear, as there is contradictory evidence as to whether or not it favors the progression of cancer [63, 79-82]. The overexpression of chemokine CCL5 in breast and cervical-uterine cancer correlates with a poor prognosis, while low plasma levels of CCL5 in patients with late stages of NSCLC correlated with long-term survival [80]. Some evidence suggests that CCL5 might contribute to the progression of NSCLC. For example, it was observed that in a TIMP2 /- murine model there is more metastasis of lung carcinoma cell lines. TIMP2 is a metalloprotease inhibitor that also inhibits the transcription of cytokines and chemokines (including CCL5) necessary for the growth of myeloid-derived suppressor cells (MDSCs) [83]. Since there is more expression of CCL5 in TIMP $2 \%$ mice, there is more recruitment of MDSCs [83]. Furthermore, it is known that the expression level of TbRII, a TGF- $\beta$ receptor, is decreased in different NSCLC cell lines [84], and this reduction is reflected in an increase in the invasive capacity of these cells. There is greater expression of CCL5 in invasive tumors and in cells with decreased expression of TbRII and inhibiting CCL5-mediated signaling abrogates the invasion of these cells [81].

Contradictorily, it seems that the expression of CCL5 also has a protective effect due to its ability to chemoattract immune effector cells to the tumor [63]. In fact, it has been reported that in response to the
CCL5 secreted by tumor cells, CD8+ T cells migrate to the tumor, where they can perform their effector functions. Patients with an active lymphocytic response (ALR) have better prognosis, and, among patients with ALR, CCL5 is a good predictor of survival [63]. This chemokine is released in the lung in response to many noxious stimuli and it has been reported that it might have antitumor activity [63]. Recently, Skachkova et al. found that patients with NSCLC who had no relapse after surgical resection, had a significant increase in the CCL5 mRNA compared to patients with relapse [79]. Finally, it is worth mentioning that 4T1 cells constitutively produces CCL5 and spontaneously metastasize to the lungs [85]. The expression of CCL5 could favor the formation of premetastatic niches since CCL5 induces the release of members of the family of chemoattractant molecules S100 [82]. In particular, tumor cells expressing CCL5 had a significant decrease in lung metastasis in $\mathrm{S100A4} /$ - mice, indicating that metastasis to this organ is strongly dependent on the interaction between CCL5 and S100A4 [86].

\section{CCL1 9 and CCL21}

CCL19 and CCL21 are homeostatic chemokines that regulate lymphocyte migration and bind to the receptor CCR7, which is expressed by naïve $\mathrm{T}$ cells and dendritic cells [87]. These chemokines are important in the activation of the local immune response, which comprises the activation of dendritic cells, the recruitment and activation of naïve $\mathrm{T}$ cells, and the formation of lymphoid structures [87]. Similarly to other neoplasms, in NSCLC the expression of chemokines CCL19 and CCL21 is important for the formation of lymph node-like structures associated with tumor tissue [88-90]. In these structures T and B lymphocytes are segregated into two adjacent regions, $\mathrm{T}$ zone and follicles, respectively, that are surrounded by specialized blood vessels called high endothelial venules [90]. CCL19 is located in the extra-follicular area, which is the concentration site of mature dendritic cells, while CCL21 is restricted to the lymphatic vessels [88]. Lymphoid structures associated to the tumor have been related to an increase in the antitumor response and with improved survival of patients $[88,89]$. In murine models of lung cancer, the presence of lymphatic structures causes a reduction of the tumor [91]. Ex vivo studies with cells from cancer patients showed that the antitumor response associated with overexpression of CCL21, depends partly on the activation and recruitment of dendritic cells and the release of chemokines CXCL9 and CXCL10[91, 92], which are induced by IFN- $\gamma$ and inhibit angiogenesis[93]. In addition, these chemokines bind to CXCR3 on T cells, increasing the secretion of 
IFN- $\gamma$ (establishing a positive feedback loop in angiostasis) and decreasing TGF- $\beta$; the latter is related to invasion processes [94]. Clinicopathological studies in patients with pulmonary adenocarcinoma have reported that the increased expression of CCR7 or CCL19 is associated with a higher life expectancy after surgical resection [95]. Immunotherapy strategies with CCL21 have been tested in NSCLC. These strategies involve the transfer of dendritic cells that overexpress this chemokine, obtaining a promising antitumor response through the activation of local dendritic cells [96-98]. In addition, nanocapsules carrying CCL21 have been injected intra-tumorally, inhibiting the growth of lung cancer [99]. However, it is worth noting that CCL21 has also been implicated in the metastasis and inhibition of apoptosis of tumor cells [100]. In this regard, microarray approaches in NSCLC showed that CCL19 could be a prognostic marker of the course of the disease associated with better survival [101].

\section{CCL25}

This chemokine specifically binds the CCR9 receptor, forming a non-promiscuous chemokine/chemokine receptor axis [11]. Recent studies show that the CCL25/CCR9 axis plays an important role on the pathophysiology of lung cancer [102, 103]. On different types of cancer (colorectal, prostatic, ovarian and breast) [104-106], the CCL25/CCR9 axis is related to the severity of the disease. In NSCLC, human neoplastic adenocarcinoma cancer and squamous cancer cells have a robust and equivalent CCR9 expression [102]. However, these two cancer subsets show differential plasma levels of CCL25, with squamous cell carcinoma having higher levels of the chemokine. In vitro studies with NSCLC cell lines show that these cells increase their migration and invasive capacity when stimulated by CCL25, with the invasion process mediated by MMPs. In squamous cell carcinoma, MMP mediates invasion, while in adenocarcinoma, both MMP2 and MMP9 play a role in this process [102]. On the other side, it has been reported that the activation of the CCL25/CCR9 axis decreases apoptosis through the positive regulation of antiapoptotic signals, and the negative regulation of proapoptotic molecules [107]. In an in vivo model, silencing of this axis with small interfering RNAs diminished the size of the tumor. This data shows that in NSCLC, like in other types of cancer, the activation of the CCL25/CCR9 axis increases the neoplastic process [107].

\section{Relevant CXC chemokines in NSCLC}

Strieter et al. showed that the angiogenic/angiostatic activity of CXC chemokines is deter- mined in most cases by the presence of the ELR amino acid motif. Thus, CXC-ELR ${ }^{+}$chemokines are angiogenic, while CXC-ELR- chemokines are angiostatic [36]. It is worth noting, however, that the chemokine CXCL12, which is an ELR- chemokine, has angiogenic activity. The CXC-ELR ${ }^{+}$group includes the chemokines CXCL1-3 and CXCL5-8 while the CXC-ELRgroup includes CXCL4, CXCL9-11 and CXCL14 [29, 108] (table 3).

\subsection{ELR+ Chemokines}

\section{CXCL8}

This chemokine has angiogenic and pro-inflammatory activity; it induces the proliferation, survival and migration of endothelial cells through its binding to CXCR1 and CXCR2 receptors, and the recruitment of neutrophils during inflammatory processes $[46,109,110]$. In contrast to SCLC cells, NSCLC cells produce substantial amounts of CXCL8 [111]. In human lung tumor tissue, the increased expression of CXCL8 is accompanied by increased vascularization and tumor growth, as well as metastasis to lymph nodes [112]. Furthermore, it has been reported that CXCL8 also has an effect on tumor cells, inducing the proliferation of lung cancer cells through CXCR1 [111] in human cells and through CXCR2 in animal models of tumor cell transfer [113]. It was recently reported that cell proliferation induced by CXCL8 involves the transactivation of the Epidermal Growth Factor Receptor (EGFR)[24], a protein overexpressed in $40-80 \%$ of NSCLC and associated with poor prognosis [2], as is also the increased expression of CXCL8 [114]. In addition, a recent report focused on grade IV lung adenocarcinoma, found that the expression of CXCL8 was associated with nutritional deterioration in patients [115]. The expression of CXCL8 is regulated by inflammatory cytokines such as TNF- $\alpha$ and IL-1 [116, 117], angiogenic molecules such as EGF [118], hypoxia [119] and the KRAS oncogene [120]. Cell lines with mutations in KRAS and EGFR have an increased expression of CXCL8, while the silencing of these molecules and treatment with tyrosine kinase inhibitors, decreases its expression [120]. Furthermore, studies on a model of human NSCLC carcinoma (H460) in immunodeficient rats suggested that the increase in serum levels of CXCL8 was associated with a decrease in the survival of animals [121].

\section{CXCL5}

This pro-inflammatory chemokine with angiogenic properties, induces neutrophil chemotaxis and is produced by epithelial cells [122]. It has been shown that density of blood vessels is greater in tumors expressing CXCL5 [123]. Arenberg et al found that 
CXCL5 is an important angiogenic factor for NSCLC and that its expression is correlated with an increase in tumor mass [124]. By immunohistochemical analysis of fresh human biopsy samples of NSCLC it was found that CXCL5 was increased. In other cancers, such as in gastric hepatocellular carcinoma cell lines, an upregulated expression of CXCL5 is associated with a high metastatic potential [125].

It is important to mention that CXCL5 has a central role in the recruitment of leukocytes in lung inflammation induced by tobacco smoke, which is the most important risk factor for developing lung cancer [126]. In this regard, it has been described that CXCL5 (along with other ligands of CXCR2) promotes the migration of pro-tumor neutrophils and induces angiogenesis [127]. In this sense, the infiltration of neutrophils promoted by CXCL5 could have some cytotoxic activity. Unfortunately, this activity is especially effective in cells with low metastatic activity [128]. It has been recently shown that HB-EGF (heparin-binding EGF-like growth factor), in combination with CXCL5, has a synergistic effect on the proliferation, migration and invasion of lung cancer [129] and in some cases, this effect is dependent on the PI3K-Akt and ERK1/2 pathway [127].

Interestingly, a study on tumor tissue obtained from patients with stage I and II NSCLC found that out of 23 genes assessed by real time PCR, only CXCL5 showed a statistically significant difference, which led to propose it as a prognostic element in these patients [130].

\section{Other CXCR2 ligands}

It is important to note that CXCL8 and CXCL5 share the receptor CXCR2 with the chemokines CXCL1-3, 6-7[11]. Little is known about the implication of these chemokines in the pathophysiology of NSCLC, even though CXCR2 is a very important receptor in NSCLC [131]. Studies using tumorigenesis models in CXCR2 $\%$ mice showed that this receptor has a central role in tumor growth, since CXCR2-deficient mice showed a significant decrease in tumor mass (associated with an increase in necrotic tissue), compared to wild type mice, while levels of the chemokines CXCL1-3 were increased [131].

\subsection{ELR-Chemokines}

CXCL9, CXCL10 and CXCL11, and their receptor CXCR3, are negative regulators of angiogenesis and are also involved in recruiting activated $\mathrm{T}$ cells and NK cells [132, 133]. There are reports that show differences in the expression of CXCL10 in different types of NSCLC. For example, the expression of this chemokine in adenocarcinoma is equivalent to normal tissue, while in lung squamous cell carcinoma the expression of CXCL10 is increased compared to normal tissue [113], and this chemokine is expressed mainly by tumor cells. It has been reported that the neutralization of CXCL10 augments vascularization in lung squamous cell carcinoma [134]. In addition, it was shown that plasma levels of CXCL10 are inversely proportional to the size of the tumor in patients and in tumorigenesis models of NSCLC in SCID mice [134]. In animal models, the intra-tumoral administration of CXCL10 for 8 weeks has an antineoplastic effect in which the size of the tumor decreases through a reduction in vascularization [113]. The metastatic activity is also partially abated, while there is an increase in apoptosis in the primary tumor. This effect appears to be dependent on the stage of the disease; if the treatment is prolonged for 10 weeks, the size of the tumor increases [134]. Interestingly, the antineoplastic effect of CXCL10 results in an increase in the survival of animals [135].

Recent studies in Lewis lung carcinoma, colon carcinoma (CT26) and breast carcinoma (4T1) murine models, tested the antitumor effect of a chimeric protein with CXCL10 and CXCL11 domains [136]. The CXCL10-CXCL11 chimeric protein was more effective than CXCL10 or CXCL11 separately in reducing the size of the tumor and inhibiting the recruitment of immune cells to the tumor infiltrate [136]. An important aspect is that in some cancers, such as colorectal carcinoma, CXCL10 has been reported to promote the invasion process through an increase in cell motility, although this does not seem to occur in primary cultures [137]. Furthermore, the chemokine CXCL9 is another ligand for the receptor CXCR3 with angiostatic function, and responsible for the recruitment of CD4+ and CD8+ T lymphocytes [138]. Apparently, there are no differences in the expression of CXCL9 in NSCLC compared with healthy lung tissue. However, in experimental models the expression of CXCL9 is associated with a decrease in vascularization and tumor size $[138,139]$.

\section{CXCL14}

This chemokine has angiostatic properties and a strong chemotactic activity for monocytes, macrophages and immature DCs [140]. CXCL14 differs from other chemokines in that it is ubiquitously distributed on normal tissue, and rarely expressed by cell lines or primary carcinomas [141, 142]. To date no receptor for this chemokine has been found [11], however recent results suggest that CXCL14 can bind glycoproteins with heparan sulfate or sialic acid, and induce proliferation and migration of NCI-H460 human lung cancer cells [143] Recently CXCL14 has appeared as an important tumor suppressing gene. The gene that codes for CXCL14 is silenced (by DNA hypermetila- 
tion) in up to $80 \%$ of colorectal carcinomas in human, and its silencing seems to contribute towards an aggressive phenotype of neoplastic cells (i.e. increased motility and invasiveness) [144]. Furthermore, a recent study showed that transgenic mice overexpressing CXCL14 had a diminished increase in the size of transplanted tumor and number of metastases, an effect probably due to NK cells since the depletion of these cells with GM1 antibodies attenuates these effects and partially restores the phenotype of wild type mice [145]. In lung cancer, the forced expression of CXCL14 in the H23 lung adenocarcinoma cell line through Decitabine (an inhibitor of DNA methylation) treatment, stimulates necrosis and tumor size, and alters the expression pattern of pro-apoptotic genes and genes related to inhibition of cell cycle and, such as caspase 4 and RBP7, respectively [108]

\section{CXCL12}

This is one of the most studied chemokines in cancer and has been shown to be important in the angiogenesis, survival and metastasis of the tumor $[25,146,147]$. It is strongly expressed in several types of tumor, including breast, pancreas and lung cancer [148]. CXCL12 binds mainly to the CXCR4 receptor, which is up-regulated by hypoxia in various cell types, such as tumor-associated macrophages [149], endothelial cells and cancer cells [149-151]. It is also regulated by inflammatory stimuli which converge into the activation of NF-кB [152]. Recent studies have shown that CXCL12 also binds with high affinity to CXCR7 [153]. In breast cancer, both receptors are overexpressed in the primary tumor and the metastases [154]. In vitro studies of breast cancer showed that the activation of the CXCL12/CXCR7 axis mainly induces angiogenesis and a moderate chemotactic and invasive response, suggesting an important role of these molecules in metastasis [38]. However, in studies on murine models, only the pharmacological inhibition of the CXCL12/CXCR4 axis was effective in reducing metastasis to lymph nodes and lung, indicating that the metastasis is mainly mediated by the CXCL12/CXCR4 axis [25].

A high expression of CXCR4 in cancer cells was reported in NSCLC, while the chemokine CXCL12 was strongly expressed in the organs affected by metastasis such as bone marrow, adrenal glands, and liver [155]. Thus, it would be possible to form chemotactic gradients of CXCL12 that direct the migration of tumor cells to metastatic sites [25]. It has been shown in vitro that CXCL12 induces chemotaxis in lung cancer cell lines, while the neutralization of CXCL12 with antibodies in animal models reduces primary tumor metastasis [155]. Furthermore, human lung adenocarcinoma A549 cells transfected with
CXCL12 have greater motility and increased expression of MMP-2 and MMP-9, which are associated with the invasion process [156]. In addition, it has been reported that the activation of CXCR4 by CXCL12 induces cancer cell survival [147].

Clinical studies in patients with grade IV pulmonary adenocarcinoma indicate that the increased expression of CXCR4 correlates with a decrease in survival of approximately 50\% [157]. Furthermore, in patients with NSCLC who underwent surgical resection, increased levels of CXCR4 were associated with brain metastasis [158], denoting the metastatic role of this chemokine.

\section{Relevant $\mathrm{CX}_{3} \mathrm{C}$ chemokines in NSCLC}

$\mathrm{CX}_{3} \mathrm{CL1}$ is the only known member of the $\mathrm{CX}_{3} \mathrm{C}$ subfamily. In contrast to other chemokines, $\mathrm{CX}_{3} \mathrm{CL1}$ can be found in two forms: tethered to the cell membrane by a mucin-like stalk, or soluble [159] after digestion of the complete protein by metalloproteases such as ADAM7 and ADAM10 [160, 161]. Each form exhibits different properties: while soluble $\mathrm{CX}_{3} \mathrm{CL1}$ is mainly a chemotactic molecule (attracting predominantly NK cells, monocytes and CD8+ T cells), membrane bound $\mathrm{CX}_{3} \mathrm{CL} 1$ is able to mediate the binding of monocytes and NK cells to the endothelium [162-164], since $\mathrm{CX}_{3} \mathrm{CL} 1$ is expressed on the surface of activated endothelial cells [165]. $\mathrm{CX}_{3} \mathrm{CR} 1$ is the only known receptor for $\mathrm{CX}_{3} \mathrm{CL1}$ [11]. The $\mathrm{CX}_{3} \mathrm{CL1} / \mathrm{CX}_{3} \mathrm{CR} 1$ axis plays a role in the recruitment of immune cells in inflammation, angiogenesis, proliferation and survival of endothelial and smooth muscle cells [166-168]. The role of the $\mathrm{CX}_{3} \mathrm{CL1} / \mathrm{CX}_{3} \mathrm{CR} 1$ axis in the neoplastic process is controversial. On the one hand, its activation has been related to pro-tumoral processes such as an increase of migration of clear cell renal cell carcinoma and proliferation in breast cancer [169, 170], while high levels of $\mathrm{CX}_{3} \mathrm{CR} 1$ or $\mathrm{CX}_{3} \mathrm{CL} 1$ expression has been associated with the metastatic status and a reduced patient survival $[169,171]$; on the other hand it has also been reported that a high expression of $\mathrm{CX}_{3} \mathrm{CL} 1$ in human breast cancer cells correlates with the infiltration of cytotoxic cells $\left(\mathrm{CD} 8^{+} \mathrm{T}\right.$ cells and NK cells) and DCs, and with higher overall patient survival [172]. The antitumor effect of the $\mathrm{CX}_{3} \mathrm{CL} 1 / \mathrm{CX}_{3} \mathrm{CR} 1$ axis is supported by studies in $\mathrm{CX}_{3} \mathrm{CR} 1 \%$ mice inoculated with B16 metastatic melanoma cells [173]. In this model, the lack of $\mathrm{CX}_{3} \mathrm{CR} 1$ was associated with larger tumors, neoplastic process-associated cachexia, and a significant reduction of recruitment of NK cells to the lungs of these mice [173]. Several studies show that, in NSCLC, the activation of the $\mathrm{CX}_{3} \mathrm{CL1} / \mathrm{CX}_{3} \mathrm{CR} 1$ axis has an important antitumor effect. Using the Lewis Lung Carcinoma (LCC) transfer model with cells expressing $\mathrm{CX}_{3} \mathrm{CL1}$ 
(3LL-FK) or mock transfected cells (3LL-mock) injected into the lung of C57BL/6, it was found that mice that received 3LL-FK cells had smaller tumors, less metastasis (up to 10 times less), and prolonged survival compared with mice inoculated with 3LL-mock cells [174, 175]. In vivo depletion of certain cell subtypes indicate that $\mathrm{CD}^{+} \mathrm{T}$ cells and NK cells have a role in the inhibition of the growth of the tumor in mice that received 3LL-FK cells [176]. Regarding the antitumoral mechanisms induced by the transfer of 3LL-FK cells, it was found that the cytotoxic activity of CTL was increased against LCC, due to DCs and NK cells. Mice that received 3LL-FK cells had an augmented number of infiltrating DCs and NK cells in the tumor. These cells were potentially recruited through the $\mathrm{CX}_{3} \mathrm{CL} 1 / \mathrm{CX}_{3} \mathrm{CR} 1$ axis, since conditioned media from 3LL-FK cells induced an in vitro migration of these cells that could be blocked with a neutralizing antibody against $\mathrm{CX}_{3} \mathrm{CL1}$, and it has been found that membrane bound $\mathrm{CX}_{3} \mathrm{CL1}$ mediates the binding of NK cells [176]. Coculture of DCs with 3LL-FK induces the maturation of DCs [174], while coculture of NK cells with 3LL-FK increases cytotoxic activity against 3LL and the production of IL-12 [176].

According to a recent publication by Savai et al., coexpression of $\mathrm{CX}_{3} \mathrm{CR} 1$ and CCR2 by tumor associated macrophages could have important therapeutic roles in NSCLC [177]. The authors explore in vitro, in vivo and ex vivo the role of TAM in the growth and metastasis of NSCLC mediated by these receptors. Macrophages from Lewis lung carcinoma infected mice were cocultured with several human NSCLC lines, resulting in an upregulation of the $\mathrm{CX}_{3} \mathrm{CL} 1 / \mathrm{CX}_{3} \mathrm{CR} 1$ and CCL2/CCR2 axis both in neoplastic cell lines and in macrophages. This upregulation correlated with an increase in carcinogenesis, particularly related to the proliferation and migration of the neoplastic cell lines. In vivo assays showed that higher expression of the $\mathrm{CX}_{3} \mathrm{CL} 1 / \mathrm{CX}_{3} \mathrm{CR} 1$ and CCL2/CCR2 axis increases the polarization of TAMs toward an M2 phenotype. When macrophages were depleted using clodronate liposomes or FAS-induced apoptosis, or when concurrently blocking the expression of CCR2 and $\mathrm{CX}_{3} \mathrm{CR} 1$, tumor growth and metastasis were inhibited; this effect was accompanied by a polarization toward the M1 phenotype, and an increase in survival of the mice [177], and the switch toward an M1 phenotype inhibited tumor growth, an effect probably related to the profile of cytokines, chemokines and growth factors secreted by macrophages.

\section{Relevant XC chemokines in NSCLC}

Chemokines belonging to this family have only two of the four conserved cysteine residues present in other chemokines. In humans there are only two members in this subfamily: XCL1 (Lymphotactin) and XCL2 (SCM1- $\beta$ ); both proteins have a very similar structure, differing in only two residues, and they have a slightly different affinity for heparin [178]. XCL1 is expressed by different lymphoid cells, including activated CD8+ T cells, CD4+ T cells and NK cells $[179,180]$; while XCL2 is expressed by macrophages, NK cells and CD8+ T Cells. Both chemokines activate the same receptor, XCR1, with virtually identical functional profiles in vitro, leading to calcium mobilization and chemotaxis [178]. In humans, the mRNA for this receptor has been detected in placenta, spleen, thymus and neutrophils [181, 182]. It is known that the activation of XCR1 by XCL1/ 2 induces the migration and proliferation of cells from human epithelial ovarian carcinoma [183]. However, the evidence about the role of XCL1/2 or XCR1 on NSCLC is scarce or non-existent. XCL1 seems to have natural adjuvant properties that might help antitumor responses by both adaptive and innate immune response, and therefore could be important in immunotherapies directed against cancer [184, 185]. For example, Cairns et al. transfected the SP2/0 myeloma cell line with the XCL1 gen before testing their ability to form tumors in mice. In this model, XCL1 expressing SP2/0 tumors regressed and became infiltrated with lymphocytes and neutrophils [185]. On the other hand Zhang et al. showed that DCs transduced with the XCL1 gene are better than WT DCs at inducing protective and therapeutic antitumor immunity through improved chemotaxis of T cells towards DCs in the tumor model of 3LL lung carcinoma [184]. These findings mean that XCL1 could play a role in the gene therapy of NSCLC.

\section{Regulation of the chemokine system through the expression of atypical recep- tors in NSCLC}

Accumulating evidence indicates that the atypical chemokine receptors may be relevant in cancer. For example, the chemokine receptor ACKR2 (also known as the Duffy antigen) inhibits growth and metastatic potential in breast cancer [186]. In vitro, the overexpression of ACKR2 in breast cancer cells (MDA-MB-231 and MDA-MB-435) inhibits proliferation and invasion; while the chemokine ligands for ACKR2 (CCL2, CCL4, CCL13 and CCL22) decreased in conditioned culture media. In vivo, D6 overexpression inhibits vessel density, tumor growth, metastasis, angiogenesis and TAM infiltration [186]. Moreover, recent studies showed that the expression of CCX-CK is involved in the metastasis of mammary carcinoma, promoting a more aggressive and motile phenotype through an increase in the expression of TGF- $\beta$ in the 
transformed cells [187].

In NSCLC studies on the A549 lung cancer line, it was shown that the overexpression of ACKR2 leads to a moderate but significant decrease in cellular proliferation [188]. In addition, the authors found a decrease in the concentration of CCL2, CCL4 and CCL5 in the conditioned culture medium, while no changes were found in the messenger RNA levels of these chemokines. Importantly, although the chemokines CCL3 and CXCL12 were tested in this study, no changes were observed in the level of these proteins as a result of the overexpression of ACKR2 [188]. Additionally, studies on a tumor transfer model using BALB/c mice showed that the overexpression of ACKR2 is accompanied by a decrease in tumor size [188]. Together, these studies indicate that the ACKR2 receptor controls the local availability of chemokines through the specific sequestration of CCL2, CCL4 and CCL5, suggesting that deregulation of the expression of this receptor could lead to changes in the tumor microenvironment, with important consequences.

\section{Concluding remarks}

In cancer, the involvement of chemokines and their receptors comprises several aspects. First, chemokines regulate, through the activation of endothelial cells, the angiogenesis that supports tumor growth. Furthermore, chemokines and their receptors contribute actively to the formation of the tumor microenvironment through the recruitment of infiltrating tumor cells such as tumor-associated macrophages. Infiltrating tumor cells change the tumor microenvironment by secreting cytokines, chemokines, growth factors, and other effector proteins (Figure 1). These molecules also contribute to the recruitment of other cell types, such as regulatory $\mathrm{T}$ cells, and are also important in the recruitment of TAN, which can contribute to genomic instability, thereby promoting the process of carcinogenesis. Moreover, it has been shown that many chemokines have direct effects on tumor cells and are able to regulate their proliferation, survival and migration. The role of angiogenesis in solid tumor growth has attracted a great deal of attention as a potential therapeutic target. Lung cancer is the main cancer-related cause of death worldwide in both men and women. Although much is still unknown about the role of chemokines in NSCLC, the evidence shown here indicates that these molecules and their receptors play a major role in the pathophysiology of this disease. Additional studies that examine the role of specific chemokine/receptor axes at different stages of lung cancer would be of great importance to understand the role of these molecules in the course of the disease and to establish the differences in the activation of chemokine receptors through different ligands.

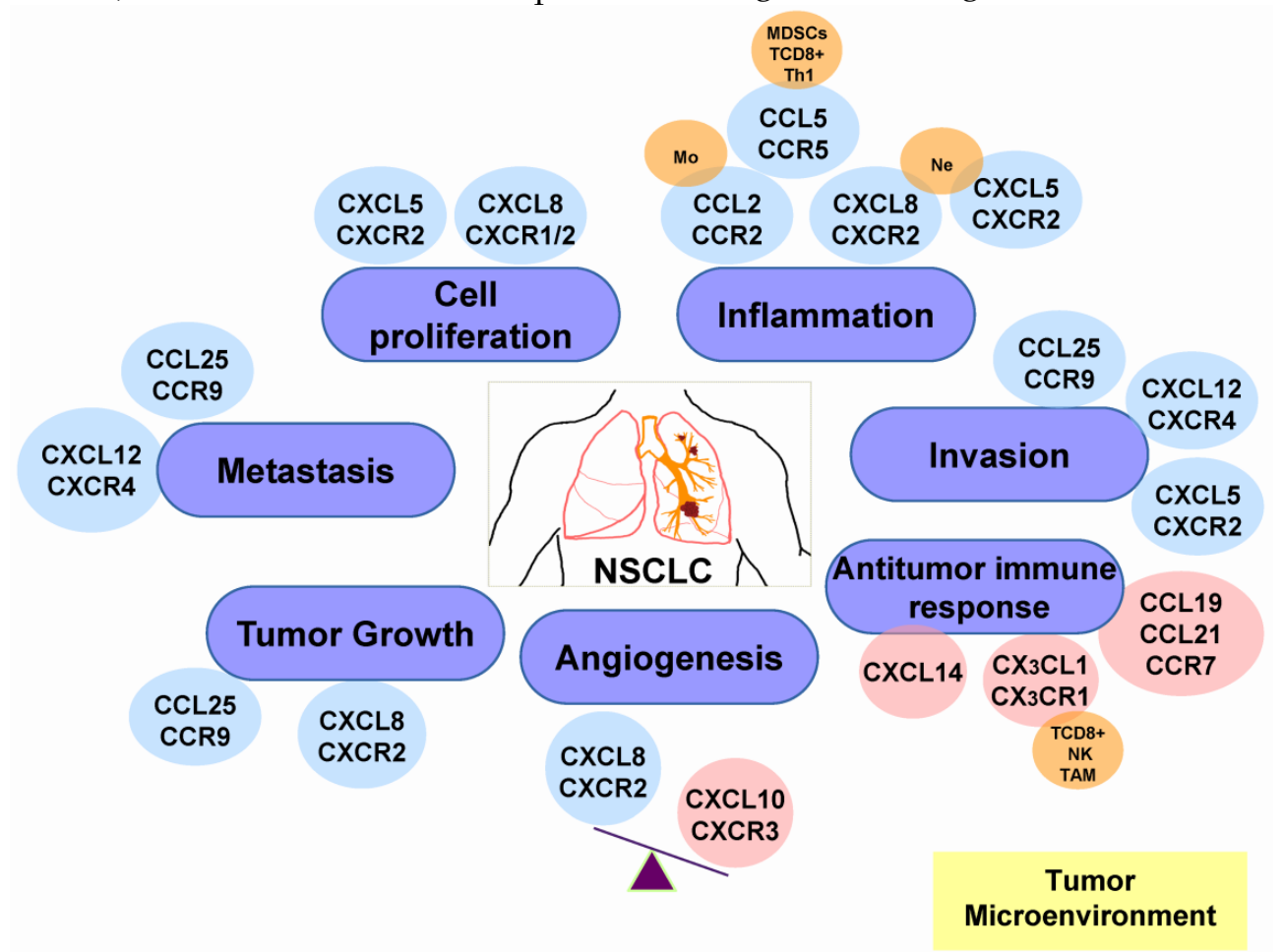

Figure 1: Chemokine ligand/receptor axis involved in the pathophysiology of NSCLC. The pathophysiology of NSCLC involves several processes, including tumor growth, angiogenesis, cell proliferation, recruitment of immune cells, invasion, metastasis, and occasionally antitumoral immune response. The figure shows the main Chemokine ligand/receptor axes involved in these processes. 


\section{Acknowledgments}

The Department of Biochemistry was partially funded by Grants 180516 from the Consejo Nacional de Ciencia y Tecnología (CONACyT), Mexico; through the Fondo Sectorial en Salud 2012. Silvana Pertuz Belloso received support from CONACyT postdoctoral fellowship program (2009-2011).

\section{Competing Interests}

\section{No competing interests were disclosed.}

\section{References}

1. Torre LA, Bray F, Siegel RL, Ferlay J, Lortet-Tieulent J, Jemal A. Global cancer statistics, 2012. CA Cancer J Clin. 2015.

2. Molina JR, Yang P, Cassivi SD, Schild SE, Adjei AA. Non-small cell lung cancer: epidemiology, risk factors, treatment, and survivorship. Mayo Clin Proc. 2008; 83: 584-594.

3. Travis WD. Pathology of lung cancer. Clin Chest Med. 2011; 32: 669-692.

4. Kataki A, Scheid P, Piet M, Marie B, Martinet N, Martinet Y, et al. Tumor infiltrating lymphocytes and macrophages have a potential dual role in lung cancer by supporting both host-defense and tumor progression. J Lab Clin Med. 2002; 140: 320-328.

5. Carus A, Ladekarl M, Hager H, Pilegaard H, Nielsen PS, Donskov F. Tumor-associated neutrophils and macrophages in non-small cell lung cancer: no immediate impact on patient outcome. Lung Cancer. 2013; 81: 130-137.

6. Coussens LM, Werb Z. Inflammation and cancer. Nature. 2002; 420: 860-867.

7. Rossi D, Zlotnik A. The biology of chemokines and their receptors. Annu Rev Immunol. 2000; 18: 217-242.

8. Thelen M, Stein JV. How chemokines invite leukocytes to dance. Nat Immunol. 2008: 9. 953-959.

9. Thelen M. Dancing to the tune of chemokines. Nat Immunol. 2001; 2: 129-134.

10. Lawrence $\mathrm{T}$. The nuclear factor NF-kappaB pathway in inflammation. Cold Spring Harb Perspect Biol. 2009; 1: a001651.

11. Bachelerie F, Ben-Baruch A, Burkhardt AM, Combadiere C, Farber JM, Graham GJ, et al. International Union of Basic and Clinical Pharmacology. [corrected]. LXXXIX. Update on the extended family of chemokine receptors and introducing a new nomenclature for atypical chemokine receptors. Pharmacol Rev. 2014; 66: 1-79.

12. Mantovani A, Sica A, Sozzani S, Allavena P, Vecchi A, Locati M. The chemokine system in diverse forms of macrophage activation and polarization. Trends Immunol. 2004; 25: 677-686.

13. Comerford I, McColl SR. Mini-review series: focus on chemokines. Immunol Cell Biol. 2011; 89: 183-184.

14. Graham GJ, Locati M, Mantovani A, Rot A, Thelen M. The biochemistry and biology of the atypical chemokine receptors. Immunol Lett. 2012; 145: 30-38.

15. Bachelerie F, Graham GJ, Locati M, Mantovani A, Murphy PM, Nibbs R, et al. New nomenclature for atypical chemokine receptors. Nat Immunol. 2014; 15: 207-208

16. Zlotnik A, Yoshie O. Chemokines: a new classification system and their role in immunity. Immunity. 2000; 12: 121-127.

17. Moser B, Wolf M, Walz A, Loetscher P. Chemokines: multiple levels of leukocyte migration control. Trends Immunol. 2004; 25: 75-84.

18. Ono SJ, Nakamura T, Miyazaki D, Ohbayashi M, Dawson M, Toda M. Chemokines: roles in leukocyte development, trafficking, and effector function. J Allergy Clin Immunol. 2003; 111: 1185-1199; quiz 1200.

19. Glabinski AR, Bielecki B, Kolodziejski P, Han Y, Selmaj K, Ransohoff RM. TNF-alpha microinjection upregulates chemokines and chemokine receptors in the central nervous system without inducing leukocyte infiltration. J Interferon Cytokine Res. 2003; 23: 457-466.

20. Neville LF, Mathiak G, Bagasra O. The immunobiology of interferon-gamma inducible protein $10 \mathrm{kD}$ (IP-10): a novel, pleiotropic member of the C-X-C chemokine superfamily. Cytokine Growth Factor Rev. 1997; 8: 207-219.

21. Hiroi M, Ohmori Y. Constitutive nuclear factor kappaB activity is required to elicit interferon-gamma-induced expression of chemokine CXC ligand 9 (CXCL9) and CXCL10 in human tumour cell lines. Biochem J. 2003; 376: 393-402.

22. Singh S, Sadanandam A, Singh RK. Chemokines in tumor angiogenesis and metastasis. Cancer Metastasis Rev. 2007; 26: 453-467.

23. Eubank TD, Roda JM, Liu H, O'Neil T, Marsh CB. Opposing roles for HIF-1alpha and HIF-2alpha in the regulation of angiogenesis by mononuclear phagocytes. Blood. 2011; 117: 323-332.

24. Luppi F, Longo AM, de Boer WI, Rabe KF, Hiemstra PS. Interleukin-8 stimulates cell proliferation in non-small cell lung cancer through epidermal growth factor receptor transactivation. Lung Cancer. 2007; 56: 25-33.

25. Muller A, Homey B, Soto H, Ge N, Catron D, Buchanan ME, et al. Involvement of chemokine receptors in breast cancer metastasis. Nature. 2001; 410: 50-56.
26. Keeley EC, Mehrad B, Strieter RM. Chemokines as mediators of neovascularization. Arterioscler Thromb Vasc Biol. 2008; 28: 1928-1936.

27. Gargett CE, Rogers PA. Human endometrial angiogenesis. Reproduction. 2001; 121: 181-186.

28. Carmeliet $P$, Jain RK. Angiogenesis in cancer and other diseases. Nature. 2000; 407: 249-257.

29. Benelli R, Lorusso G, Albini A, Noonan DM. Cytokines and chemokines as regulators of angiogenesis in health and disease. Curr Pharm Des. 2006; 12: 3101-3115

30. Carmeliet P, Jain RK. Molecular mechanisms and clinical applications of angiogenesis. Nature. 2011; 473: 298-307.

31. Distler JH, Hirth A, Kurowska-Stolarska M, Gay RE, Gay S, Distler O. Angiogenic and angiostatic factors in the molecular control of angiogenesis. Q Nucl Med. 2003; 47: 149-161.

32. Lamalice L, Le Boeuf F, Huot J. Endothelial cell migration during angiogenesis. Circ Res. 2007; 100: 782-794.

33. Szekanecz Z, Koch AE. Vascular involvement in rheumatic diseases: 'vascular rheumatology'. Arthritis Res Ther. 2008; 10: 224.

34. Strieter RM, Polverini PJ, Arenberg DA, Kunkel SL. The role of CXC chemokines as regulators of angiogenesis. Shock. 1995; 4: 155-160.

35. Moore BB, Arenberg DA, Addison CL, Keane MP, Polverini PJ, Strieter RM. CXC chemokines mechanism of action in regulating tumor angiogenesis. Angiogenesis. 1998; 2: 123-134.

36. Strieter RM, Polverini PJ, Kunkel SL, Arenberg DA, Burdick MD, Kasper J, et al. The functional role of the ELR motif in CXC chemokine-mediated angiogenesis. J Biol Chem. 1995; 270: 27348-27357.

37. Mirshahi F, Pourtau J, Li H, Muraine M, Trochon V, Legrand E, et al. SDF-1 activity on microvascular endothelial cells: consequences on angiogenesis in in vitro and in vivo models. Thromb Res. 2000; 99: 587-594.

38. Hernandez L, Magalhaes MA, Coniglio SJ, Condeelis JS, Segall JE. Opposing roles of CXCR4 and CXCR7 in breast cancer metastasis. Breast Cancer Res. 2011; 13: R128.

39. Hoeben A, Landuyt B, Highley MS, Wildiers H, Van Oosterom AT, De Bruijn EA. Vascular endothelial growth factor and angiogenesis. Pharmacol Rev. 2004; 56: 549-580.

40. Bardos JI, Ashcroft M. Hypoxia-inducible factor-1 and oncogenic signalling. Bioessays. 2004; 26: 262-269.

41. Weidemann A, Johnson RS. Biology of HIF-1alpha. Cell Death Differ. 2008; 15: 621-627.

42. Folkman J. What is the evidence that tumors are angiogenesis dependent? J Natl Cancer Inst. 1990; 82: 4-6.

43. Rucci N, Sanita P, Angelucci A. Roles of metalloproteases in metastatic niche. Curr Mol Med. 2011; 11: 609-622.

44. Fang W, Li H, Kong L, Niu G, Gao Q, Zhou K, et al. [Role of matrix metalloproteinases (MMPs) in tumor invasion and metastasis: serial studies on MMPs and TIMPs]. Beijing Da Xue Xue Bao. 2003; 35: 441-443.

45. Pan F, Ma S, Cao W, Liu H, Chen F, Chen X, et al. SDF-1alpha upregulation of MMP-2 is mediated by p38 MAPK signaling in pancreatic cancer cell lines. Mol Biol Rep.2013;40: 4139-4146.

46. Li A, Varney ML, Valasek J, Godfrey M, Dave BJ, Singh RK. Autocrine role of interleukin-8 in induction of endothelial cell proliferation, survival, migration and MMP-2 production and angiogenesis. Angiogenesis. 2005; 8: 63-71.

47. McQuibban GA, Gong JH, Tam EM, McCulloch CA, Clark-Lewis I, Overall CM. Inflammation dampened by gelatinase A cleavage of monocyte chemoattractant protein-3. Science. 2000; 289: 1202-1206.

48. McQuibban GA, Butler GS, Gong JH, Bendall L, Power C, Clark-Lewis I, et al. Matrix metalloproteinase activity inactivates the CXC chemokine stromal cell-derived factor-1. J Biol Chem. 2001; 276: 43503-43508.

49. Koontongkaew $\mathrm{S}$. The tumor microenvironment contribution to development, growth, invasion and metastasis of head and neck squamous cell carcinomas. J Cancer. 2013; 4: 66-83.

50. Mizutani K, Sud S, McGregor NA, Martinovski G, Rice BT, Craig MJ, et al. The chemokine CCL2 increases prostate tumor growth and bone metastasis through macrophage and osteoclast recruitment. Neoplasia. 2009; 11: 1235-1242.

51. Santoni M, Massari F, Amantini C, Nabissi M, Maines F, Burattini L, et al. Emerging role of tumor-associated macrophages as therapeutic targets in patients with metastatic renal cell carcinoma. Cancer Immunol Immunother. 2013; 62: 1757-1768.

52. Mukaida N, Baba T. Chemokines in tumor development and progression. Exp Cell Res. 2012; 318: 95-102.

53. Galdiero MR, Garlanda C, Jaillon S, Marone G, Mantovani A. Tumor associated macrophages and neutrophils in tumor progression. J Cell Physiol. 2013; 228: 1404-1412.

54. Burkhardt AM, Maravillas-Montero JL, Carnevale CD, Vilches-Cisneros N, Flores JP, Hevezi PA, et al. CXCL17 is a major chemotactic factor for lung macrophages. J Immunol. 2014; 193: 1468-1474.

55. Zhao JJ, Pan K, Wang W, Chen JG, Wu YH, Lv L, et al. The prognostic value of tumor-infiltrating neutrophils in gastric adenocarcinoma after resection. PLoS One. 2012; 7: e33655.

56. Gungor N, Knaapen AM, Munnia A, Peluso M, Haenen GR, Chiu RK, et al. Genotoxic effects of neutrophils and hypochlorous acid. Mutagenesis. 2010; 25: $149-154$ 
57. Shabani F, McNeil J, Tippett L. The oxidative inactivation of tissue inhibitor of metalloproteinase-1 (TIMP-1) by hypochlorous acid (HOCI) is suppressed by anti-rheumatic drugs. Free Radic Res. 1998; 28: 115-123.

58. Galdiero MR, Bonavita E, Barajon I, Garlanda C, Mantovani A, Jaillon S. Tumor associated macrophages and neutrophils in cancer. Immunobiology. 2013; 218: 1402-1410.

59. Naito Y, Saito K, Shiiba K, Ohuchi A, Saigenji K, Nagura H, et al. CD8+ T cells infiltrated within cancer cell nests as a prognostic factor in human colorectal cancer. Cancer Res. 1998; 58: 3491-3494.

60. Mizukami Y, Kono K, Kawaguchi Y, Akaike H, Kamimura K, Sugai H, et al. CCL17 and CCL22 chemokines within tumor microenvironment are related to accumulation of Foxp3+ regulatory T cells in gastric cancer. Int J Cancer. 2008; 122: 2286-2293.

61. Maruyama T, Kono K, Mizukami Y, Kawaguchi Y, Mimura K, Watanabe M, et al. Distribution of Th17 cells and FoxP3 $(+)$ regulatory $\mathrm{T}$ cells in tumor-infiltrating lymphocytes, tumor-draining lymph nodes and peripheral blood lymphocytes in patients with gastric cancer. Cancer Sci. 2010; 101: 1947-1954.

62. Mailloux AW, Young MR. NK-dependent increases in CCL22 secretion selectively recruits regulatory $\mathrm{T}$ cells to the tumor microenvironment. J Immunol. 2009: 182: 2753-2765.

63. Moran CJ, Arenberg DA, Huang CC, Giordano TJ, Thomas DG, Misek DE, et al. RANTES expression is a predictor of survival in stage I lung adenocarcinoma. Clin Cancer Res. 2002; 8: 3803-3812.

64. Yuan A, Yang PC, Yu CJ, Chen WJ, Lin FY, Kuo SH, et al. Interleukin-8 messenger ribonucleic acid expression correlates with tumor progression, tumor angiogenesis, patient survival, and timing of relapse in non-small-cell lung cancer. Am J Respir Crit Care Med. 2000; 162: 1957-1963.

65. Nesbeth Y, Scarlett U, Cubillos-Ruiz J, Martinez D, Engle X, Turk MJ, et al. CCL5-mediated endogenous antitumor immunity elicited by adoptively transferred lymphocytes and dendritic cell depletion. Cancer Res. 2009; 69: 6331-6338.

66. Ohri CM, Shikotra A, Green RH, Waller DA, Bradding P. Chemokine receptor expression in tumour islets and stroma in non-small cell lung cancer. BMC Cancer. 2010; 10: 172

67. Loberg RD, Ying C, Craig M, Yan L, Snyder LA, Pienta KJ. CCL2 as an important mediator of prostate cancer growth in vivo through the regulation of macrophage infiltration. Neoplasia. 2007; 9: 556-562.

68. Salcedo R, Ponce ML, Young HA, Wasserman K, Ward JM, Kleinman HK, et al. Human endothelial cells express CCR2 and respond to MCP-1: direct role of MCP-1 in angiogenesis and tumor progression. Blood. 2000; 96: 34-40.

69. Stamatovic SM, Keep RF, Mostarica-Stojkovic M, Andjelkovic AV. CCL2 regulates angiogenesis via activation of Ets-1 transcription factor. J Immunol. 2006; 177: 2651-2661.

70. Steiner JL, Murphy EA. Importance of chemokine (CC-motif) ligand 2 in breast cancer. Int J Biol Markers. 2012; 27: e179-185.

71. Arenberg DA, Keane MP, DiGiovine B, Kunkel SL, Strom SR, Burdick MD, et al. Macrophage infiltration in human non-small-cell lung cancer: the role of CC chemokines. Cancer Immunol Immunother. 2000; 49: 63-70.

72. Yoshimura T, Howard OM, Ito T, Kuwabara M, Matsukawa A, Chen K, et al. Monocyte chemoattractant protein-1/CCL2 produced by stromal cells promotes lung metastasis of 4T1 murine breast cancer cells. PLoS One. 2013; 8: e58791.

73. Fridlender ZG, Kapoor V, Buchlis G, Cheng G, Sun J, Wang LC, et al. Monocyte chemoattractant protein-1 blockade inhibits lung cancer tumor growth by altering macrophage phenotype and activating CD8+ cells. Am J Respir Cell Mol Biol. 2011; 44: 230-237

74. Huang B, Lei Z, Zhao J, Gong W, Liu J, Chen Z, et al. CCL2/CCR2 pathway mediates recruitment of myeloid suppressor cells to cancers. Cancer Lett. 2007; 252: 86-92.

75. Zhao L, Lim SY, Gordon-Weeks AN, Tapmeier TT, Im JH, Cao Y, et al. Recruitment of a myeloid cell subset (CD11b/Gr1 mid) via CCL2/CCR2 promotes the development of colorectal cancer liver metastasis. Hepatology. 2013; 57: 829-839.

76. Lu X, Kang Y. Chemokine (C-C motif) ligand 2 engages CCR2+ stromal cells of monocytic origin to promote breast cancer metastasis to lung and bone. J Biol Chem. 2009; 284: 29087-29096

77. Zhang XW, Qin X, Qin CY, Yin YL, Chen Y, Zhu HL. Expression of monocyte chemoattractant protein-1 and CC chemokine receptor 2 in non-small cell lung cancer and its significance. Cancer Immunol Immunother. 2013; 62: 563-570.

78. Lee HJ, Kim YT, Park PJ, Shin YS, Kang KN, Kim Y, et al. A novel detection method of non-small cell lung cancer using multiplexed bead-based serum biomarker profiling. J Thorac Cardiovasc Surg. 2012; 143: 421-427.

79. Skachkova OV, Khranovska NM, Gorbach OI, Svergun NM, Sydor RI, Nikulina VV. Immunological markers of anti-tumor dendritic cells vaccine efficiency in patients with non-small cell lung cancer. Exp Oncol. 2013; 35: 109-113

80. Umekawa K, Kimura T, Kudoh S, Suzumura T, Oka T, Nagata M, et al. Plasma RANTES, IL-10, and IL-8 levels in non-small-cell lung cancer patients treated with EGFR-TKIs. BMC Res Notes. 2013; 6: 139.

81. Borczuk AC, Papanikolaou N, Toonkel RL, Sole M, Gorenstein LA, Ginsburg ME, et al. Lung adenocarcinoma invasion in TGFbetaRII-deficient cells is mediated by CCL5/RANTES. Oncogene. 2008; 27: 557-564.
82. Forst $B$, Hansen MT, Klingelhofer J, Moller HD, Nielsen GH, Grum-Schwensen B, et al. Metastasis-inducing S100A4 and RANTES cooperate in promoting tumor progression in mice. PLoS One. 2010; 5: e10374.

83. Guedez L, Jensen-Taubman S, Bourboulia D, Kwityn CJ, Wei B, Caterina I, et al. TIMP-2 targets tumor-associated myeloid suppressor cells with effects in cancer immune dysfunction and angiogenesis. J Immunother. 2012; 35: 502-512.

84. Kim TK, Mo EK, Yoo CG, Lee CT, Han SK, Shim YS, et al. Alteration of cell growth and morphology by overexpression of transforming growth factor beta type II receptor in human lung adenocarcinoma cells. Lung Cancer. 2001; 31: 181-191.

85. Stormes KA, Lemken CA, Lepre JV, Marinucci MN, Kurt RA. Inhibition of metastasis by inhibition of tumor-derived CCL5. Breast Cancer Res Treat. 2005; 89: 209-212.

86. Borsig L, Wolf MJ, Roblek M, Lorentzen A, Heikenwalder M. Inflammatory chemokines and metastasis--tracing the accessory. Oncogene. 2014; 33: 3217-3224.

87. Comerford I, Harata-Lee Y, Bunting MD, Gregor C, Kara EE, McColl SR. A myriad of functions and complex regulation of the CCR7/CCL19/CCL21 chemokine axis in the adaptive immune system. Cytokine Growth Factor Rev. 2013; 24: 269-283.

88. de Chaisemartin L, Goc J, Damotte D, Validire P, Magdeleinat P, Alifano M, et al. Characterization of chemokines and adhesion molecules associated with $\mathrm{T}$ cell presence in tertiary lymphoid structures in human lung cancer. Cancer Res. 2011; 71: 6391-6399.

89. Dieu-Nosjean MC, Antoine M, Danel C, Heudes D, Wislez M, Poulot V, et al. Long-term survival for patients with non-small-cell lung cancer with intratumoral lymphoid structures. J Clin Oncol. 2008; 26: 4410-4417.

90. Goc J, Fridman WH, Sautes-Fridman C, Dieu-Nosjean MC. Characteristics of tertiary lymphoid structures in primary cancers. Oncoimmunology. 2013; 2: e26836.

91. Sharma S, Yang SC, Hillinger S, Zhu LX, Huang M, Batra RK, et al. SLC/CCL21-mediated anti-tumor responses require IFNgamma, MIG/CXCL9 and IP-10/CXCL10. Mol Cancer. 2003; 2: 22.

92. Riedl K, Baratelli F, Batra RK, Yang SC, Luo J, Escuadro B, et al. Overexpression of CCL-21/secondary lymphoid tissue chemokine in human dendritic cells augments chemotactic activities for lymphocytes and antigen presenting cells. Mol Cancer. 2003; 2: 35.

93. Yang J, Richmond A. The angiostatic activity of interferon-inducible protein-10/CXCL10 in human melanoma depends on binding to CXCR3 but not to glycosaminoglycan. Mol Ther. 2004; 9: 846-855.

94. Welch DR, Fabra A, Nakajima M. Transforming growth factor beta stimulates mammary adenocarcinoma cell invasion and metastatic potential. Proc Natl Acad Sci U S A. 1990; 87: 7678-7682.

95. Itakura M, Terashima Y, Shingyoji M, Yokoi S, Ohira M, Kageyama H, et al. High CC chemokine receptor 7 expression improves postoperative prognosis of lung adenocarcinoma patients. Br J Cancer. 2013; 109: 1100-1108.

96. Yang SC, Hillinger S, Riedl K, Zhang L, Zhu L, Huang M, et al. Intratumoral administration of dendritic cells overexpressing CCL21 generates systemic antitumor responses and confers tumor immunity. Clin Cancer Res. 2004; 10: 2891-2901.

97. Perrot I, Blanchard D, Freymond N, Isaac S, Guibert B, Pacheco Y, et al. Dendritic cells infiltrating human non-small cell lung cancer are blocked at immature stage. J Immunol. 2007; 178: 2763-2769.

98. Baratelli F, Takedatsu $\mathrm{H}$, Hazra S, Peebles K, Luo J Kurimoto PS, et al. Pre-clinical characterization of GMP grade CCL21-gene modified dendritic cells for application in a phase I trial in non-small cell lung cancer. J Transl Med. 2008; 6: 38

99. Kar UK, Srivastava MK, Andersson A, Baratelli F, Huang M, Kickhoefer VA, et al. Novel CCL21-vault nanocapsule intratumoral delivery inhibits lung cancer growth. PLoS One. 2011; 6: e18758.

100. Xu Y, Liu L, Qiu X, Liu Z, Li H, Li Z, et al. CCL21/CCR7 prevents apoptosis via the ERK pathway in human non-small cell lung cancer cells. PLoS One. 2012; 7: e33262.

101. Lee ES, Son DS, Kim SH, Lee J, Jo J, Han J, et al. Prediction of recurrence-free survival in postoperative non-small cell lung cancer patients by using an integrated model of clinical information and gene expression. Clin Cancer Res. 2008; 14: 7397-7404.

102. Gupta P, Sharma PK, Mir $\mathrm{H}$, Singh $\mathrm{R}$, Singh $\mathrm{N}$, Kloecker $\mathrm{GH}$, et al. CCR9/CCL25 expression in non-small cell lung cancer correlates with aggressive disease and mediates key steps of metastasis. Oncotarget. 2014; 5: 10170-10179.

103. Li B, Wang Z, Zhong Y, Lan J, Li X, Lin H. CCR9-CCL25 interaction suppresses apoptosis of lung cancer cells by activating the PI3K/Akt pathway. Med Oncol. 2015; 32: 66 .

104. Singh R, Stockard CR, Grizzle WE, Lillard JW, Jr., Singh S. Expression and histopathological correlation of CCR9 and CCL25 in ovarian cancer. Int J Oncol. 2011; 39: 373-381.

105. Johnson EL, Singh R, Singh S, Johnson-Holiday CM, Grizzle WE, Partridge EE, et al. CCL25-CCR9 interaction modulates ovarian cancer cell migration, metalloproteinase expression, and invasion. World J Surg Oncol. 2010; 8: 62.

106. Johnson-Holiday C, Singh R, Johnson E, Singh S, Stockard CR, Grizzle WE, et al. CCL25 mediates migration, invasion and matrix metalloproteinase expression by breast cancer cells in a CCR9-dependent fashion. Int J Oncol. 2011; 38: 1279-1285. 
107. Li B, Wang Z, Zhong Y, Lan J, Li X, Lin H. CCR9-CCL25 interaction suppresses apoptosis of lung cancer cells by activating the PI3K/Akt pathway. Med Oncol. 2015; 32: 531.

108. Tessema M, Klinge DM, Yingling CM, Do K, Van Neste L, Belinsky SA. Re-expression of CXCL14, a common target for epigenetic silencing in lung cancer, induces tumor necrosis. Oncogene. 2010; 29: 5159-5170.

109. Singh S, Wu S, Varney M, Singh AP, Singh RK. CXCR1 and CXCR2 silencing modulates CXCL8-dependent endothelial cell proliferation, migration and capillary-like structure formation. Microvasc Res. 2011; 82: 318-325.

110. Russo RC, Garcia CC, Teixeira MM, Amaral FA. The CXCL8/IL-8 chemokine family and its receptors in inflammatory diseases. Expert Rev Clin Immunol. 2014; 10: 593-619.

111. Zhu YM, Webster SJ, Flower D, Woll PJ. Interleukin-8/CXCL8 is a growth factor for human lung cancer cells. Br J Cancer. 2004; 91: 1970-1976.

112. Xu C, Bian X, Wang Q, Zhang R, Chen C, Ye Q. [Detection of interleukin-8 on tissue array of non-small cell lung cancer and its clinicopathological significance]. Zhongguo Fei Ai Za Zhi. 2007; 10: 386-390.

113. Arenberg DA, Kunkel SL, Polverini PJ, Glass M, Burdick MD, Strieter RM. Inhibition of interleukin-8 reduces tumorigenesis of human non-small cell lung cancer in SCID mice. J Clin Invest. 1996; 97: 2792-2802.

114. Ryan BM, Pine SR, Chaturvedi AK, Caporaso N, Harris CC. A Combined Prognostic Serum Interleukin-8 and Interleukin-6 Classifier for Stage 1 Lung Cancer in the Prostate, Lung, Colorectal, and Ovarian Cancer Screening Trial. J Thorac Oncol. 2014.

115. Gioulbasanis I, Patrikidou A, Kitikidou K, Papadimitriou K, Vlachostergios PJ, Tsatsanis C, et al. Baseline plasma levels of interleukin-8 in stage IV non-small-cell lung cancer patients: relationship with nutritional status and prognosis. Nutr Cancer. 2012; 64: 41-47.

116. Mizuno K, Sone S, Orino E, Mukaida N, Matsushima K, Ogura T. Spontaneous production of interleukin- 8 by human lung cancer cells and its augmentation by tumor necrosis factor alpha and interleukin-1 at protein and mRNA levels. Oncology. 1994; 51: 467-471.

117. Yao PL, Lin YC, Wang CH, Huang YC, Liao WY, Wang SS, et al. Autocrine and paracrine regulation of interleukin-8 expression in lung cancer cells. Am J Respir Cell Mol Biol. 2005; 32: 540-547.

118. Zhang Y, Wang L, Zhang M, Jin M, Bai C, Wang X. Potential mechanism of interleukin-8 production from lung cancer cells: an involvement of EGF-EGFR-PI3K-Akt-Erk pathway. J Cell Physiol. 2012; 227: 35-43.

119. Chiang YY. Hepatocyte growth factor induces hypoxia-related interleukin-8 expression in lung adenocarcinoma cells. Mol Carcinog. 2009; 48: 662-670.

120. Sunaga N, Imai H, Shimizu K, Shames DS, Kakegawa S, Girard L, et al. Oncogenic KRAS-induced interleukin-8 overexpression promotes cell growth and migration and contributes to aggressive phenotypes of non-small cell lung cancer. Int J Cancer. 2012; 130: 1733-1744.

121. Millar HJ, Nemeth JA, McCabe FL, Pikounis B, Wickstrom E. Circulating human interleukin-8 as an indicator of cancer progression in a nude rat orthotopic human non-small cell lung carcinoma model. Cancer Epidemiol Biomarkers Prev. 2008; 17: 2180-2187.

122. Walz A, Schmutz P, Mueller C, Schnyder-Candrian S. Regulation and function of the CXC chemokine ENA-78 in monocytes and its role in disease. J Leukoc Biol. 1997; 62: 604-611.

123. Park JY, Park KH, Bang S, Kim MH, Lee JE, Gang J, et al. CXCL5 overexpression is associated with late stage gastric cancer. J Cancer Res Clin Oncol. 2007; 133: 835-840.

124. Arenberg DA, Keane MP, DiGiovine B, Kunkel SL, Morris SB, Xue YY, et al. Epithelial-neutrophil activating peptide (ENA-78) is an important angiogenic factor in non-small cell lung cancer. J Clin Invest. 1998; 102: 465-472.

125. Parihar JS, Tunuguntla HS. Role of chemokines in renal cell carcinoma. Rev Urol. 2014; 16: 118-121.

126. Balamayooran G, Batra S, Cai S, Mei J, Worthen GS, Penn AL, et al. Role of CXCL5 in leukocyte recruitment to the lungs during secondhand smoke exposure. Am J Respir Cell Mol Biol. 2012; 47: 104-111.

127. Zhou SL, Dai Z, Zhou ZJ, Wang XY, Yang GH, Wang Z, et al. Overexpression of CXCL5 mediates neutrophil infiltration and indicates poor prognosis for hepatocellular carcinoma. Hepatology. 2012; 56: 2242-2254.

128. Verbeke H, Geboes K, Van Damme J, Struyf S. The role of CXC chemokines in the transition of chronic inflammation to esophageal and gastric cancer. Biochim Biophys Acta. 2012; 1825: 117-129.

129. Kuo PL, Huang MS, Hung JY, Chou SH, Chiang SY, Huang YF, et al. Synergistic effect of lung tumor-associated dendritic cell-derived HB-EGF and CXCL5 on cancer progression. Int J Cancer. 2014; 135: 96-108.

130. Kowalczuk O, Burzykowski T, Niklinska WE, Kozlowski M, Chyczewski L, Niklinski J. CXCL5 as a potential novel prognostic factor in early stage non-small cell lung cancer: results of a study of expression levels of 23 genes. Tumour Biol. 2014; 35: 4619-4628.

131. Keane MP, Belperio JA, Xue YY, Burdick MD, Strieter RM. Depletion of CXCR2 inhibits tumor growth and angiogenesis in a murine model of lung cancer. J Immunol. 2004; 172: 2853-2860.

132. Lande R, Giacomini E, Grassi $T$, Remoli ME Iona $E$, Miettinen $M$, et al. IFN-alpha beta released by Mycobacterium tuberculosis-infected human dendritic cells induces the expression of CXCL10: selective recruitment of NK and activated T cells. J Immunol. 2003; 170: 1174-1182.

133. Christensen JE, de Lemos C, Moos T, Christensen JP, Thomsen AR. CXCL10 is the key ligand for CXCR3 on CD8+ effector T cells involved in immune surveillance of the lymphocytic choriomeningitis virus-infected central nervous system. J Immunol. 2006; 176: 4235-4243.

134. Arenberg DA, Kunkel SL, Polverini PJ, Morris SB, Burdick MD, Glass MC, et al. Interferon-gamma-inducible protein 10 (IP-10) is an angiostatic factor that inhibits human non-small cell lung cancer (NSCLC) tumorigenesis and spontaneous metastases. J Exp Med. 1996; 184: 981-992.

135. Arenberg DA, White ES, Burdick MD, Strom SR, Strieter RM. Improved survival in tumor-bearing SCID mice treated with interferon-gamma-inducible protein 10 (IP-10/CXCL10). Cancer Immunol Immunother. 2001; 50: 533-538.

136. Wang $\mathrm{P}$, Yang $\mathrm{X}, \mathrm{Xu} \mathrm{W}, \mathrm{Li} \mathrm{K}, \mathrm{Chu} \mathrm{Y}$, Xiong $\mathrm{S}$. Integrating individual functional moieties of CXCL10 and CXCL11 into a novel chimeric chemokine leads to synergistic antitumor effects: a strategy for chemokine-based multi-target-directed cancer therapy. Cancer Immunol Immunother. 2010; 59: 1715-1726.

137. Zipin-Roitman A, Meshel T, Sagi-Assif O, Shalmon B, Avivi C, Pfeffer RM, et al. CXCL10 promotes invasion-related properties in human colorectal carcinoma cells. Cancer Res. 2007; 67: 3396-3405.

138. Flier J, Boorsma DM, van Beek PJ, Nieboer C, Stoof TJ, Willemze R, et al. Differential expression of CXCR3 targeting chemokines CXCL10, CXCL9, and CXCL11 in different types of skin inflammation. J Pathol. 2001; 194: 398-405.

139. Addison CL, Arenberg DA, Morris SB, Xue YY, Burdick MD, Mulligan MS, et al. The CXC chemokine, monokine induced by interferon-gamma, inhibits non-small cell lung carcinoma tumor growth and metastasis. Hum Gene Ther. 2000; 11: 247-261.

140. Shellenberger TD, Wang M, Gujrati M, Jayakumar A, Strieter RM, Burdick $\mathrm{MD}$, et al. BRAK/CXCL14 is a potent inhibitor of angiogenesis and a chemotactic factor for immature dendritic cells. Cancer Res. 2004; 64: 8262-8270.

141. Hromas R, Broxmeyer HE, Kim C, Nakshatri H, Christopherson K, 2nd, Azam $\mathrm{M}$, et al. Cloning of BRAK, a novel divergent CXC chemokine preferentially expressed in normal versus malignant cells. Biochem Biophys Res Commun. 1999; 255: 703-706.

142. Shurin GV, Ferris RL, Tourkova IL, Perez L, Lokshin A, Balkir L, et al. Loss of new chemokine CXCL14 in tumor tissue is associated with low infiltration by dendritic cells (DC), while restoration of human CXCL14 expression in tumor cells causes attraction of DC both in vitro and in vivo. J Immunol. 2005; 174: 5490-5498.

143. Park CR, You DJ, Kim DK, Moon MJ, Lee C, Oh SH, et al. CXCL14 enhances proliferation and migration of NCI-H460 human lung cancer cells overexpressing the glycoproteins containing heparan sulfate or sialic acid. J Cell Biochem. 2013; 114: 1084-1096.

144. Cao B, Yang Y, Pan Y, Jia Y, Brock MV, Herman JG, et al. Epigenetic silencing of CXCL14 induced colorectal cancer migration and invasion. Discov Med. 2013; 16: 137-147.

145. Hata R, Izukuri K, Kato Y, Sasaki S, Mukaida N, Maehata Y, et al. Suppressed rate of carcinogenesis and decreases in tumour volume and lung metastasis in CXCL14/BRAK transgenic mice. Sci Rep. 2015; 5: 9083.

146. Cui K, Zhao W, Wang C, Wang A, Zhang B, Zhou W, et al. The CXCR4-CXCL12 pathway facilitates the progression of pancreatic cancer via induction of angiogenesis and lymphangiogenesis. J Surg Res. 2011; 171: 143-150.

147. Wagner PL, Hyjek E, Vazquez MF, Meherally D, Liu YF, Chadwick PA, et al. CXCL12 and CXCR4 in adenocarcinoma of the lung: association with metastasis and survival. J Thorac Cardiovasc Surg. 2009; 137: 615-621.

148. Kryczek I, Wei S, Keller E, Liu R, Zou W. Stroma-derived factor (SDF-1/CXCL12) and human tumor pathogenesis. Am J Physiol Cell Physiol. 2007; 292: C987-995.

149. Schioppa T, Uranchimeg B, Saccani A, Biswas SK, Doni A, Rapisarda A, et al. Regulation of the chemokine receptor CXCR4 by hypoxia. J Exp Med. 2003; 198: 1391-1402.

150. Oh YS, Kim HY, Song IC, Yun HJ, Jo DY, Kim S, et al. Hypoxia induces CXCR4 expression and biological activity in gastric cancer cells through activation of hypoxia-inducible factor-1alpha. Oncol Rep. 2012; 28: 2239-2246.

151. Cronin PA, Wang JH, Redmond HP. Hypoxia increases the metastatic ability of breast cancer cells via upregulation of CXCR4. BMC Cancer. 2010; 10: 225.

152. Ruffini PA, Morandi P, Cabioglu N, Altundag K, Cristofanilli M. Manipulating the chemokine-chemokine receptor network to treat cancer. Cancer. 2007; 109: 2392-2404.

153. Singh AK, Arya RK, Trivedi AK, Sanyal S, Baral R, Dormond O, et al. Chemokine receptor trio: CXCR3, CXCR4 and CXCR7 crosstalk via CXCL11 and CXCL12. Cytokine Growth Factor Rev. 2013; 24: 41-49.

154. Sun X, Cheng G, Hao M, Zheng J, Zhou X, Zhang J, et al. CXCL12 / CXCR4 / CXCR7 chemokine axis and cancer progression. Cancer Metastasis Rev. 2010; 29: 709-722.

155. Phillips RJ, Burdick MD, Lutz M, Belperio JA, Keane MP, Strieter RM. The stromal derived factor-1/CXCL12-CXC chemokine receptor 4 biological axis in non-small cell lung cancer metastases. Am J Respir Crit Care Med. 2003; 167: 1676-1686.

156. Dai X, Mao Z, Huang J, Xie S, Zhang H. The CXCL12/CXCR4 autocrine loop increases the metastatic potential of non-small cell lung cancer in vitro. Oncol Lett. 2013; 5: 277-282.

157. Otsuka S, Klimowicz AC, Kopciuk K, Petrillo SK, Konno M, Hao D, et al. CXCR4 overexpression is associated with poor outcome in females diagnosed with stage IV non-small cell lung cancer. J Thorac Oncol. 2011; 6: 1169-1178. 
158. Chen G, Wang Z, Liu XY, Liu FY. High-level CXCR4 expression correlates with brain-specific metastasis of non-small cell lung cancer. World J Surg. 2011; 35: 56-61.

159. Bazan JF, Bacon KB, Hardiman G, Wang W, Soo K, Rossi D, et al. A new class of membrane-bound chemokine with a CX3C motif. Nature. 1997; 385: 640-644.

160. Hundhausen C, Misztela D, Berkhout TA, Broadway N, Saftig P, Reiss K, et al. The disintegrin-like metalloproteinase ADAM10 is involved in constitutive cleavage of CX3CL1 (fractalkine) and regulates CX3CL1-mediated cell-cell adhesion. Blood. 2003; 102: 1186-1195.

161. Jones BA, Beamer M, Ahmed S. Fractalkine/CX3CL1: a potential new target for inflammatory diseases. Mol Interv. 2010; 10: 263-270.

162. Imai $T$, Hieshima $K$, Haskell $C$, Baba M, Nagira M, Nishimura $M$, et al. Identification and molecular characterization of fractalkine receptor CX3CR1, which mediates both leukocyte migration and adhesion. Cell. 1997; 91: 521-530.

163. Robinson LA, Nataraj C, Thomas DW, Cosby JM, Griffiths R, Bautch VL, et al. The chemokine CX3CL1 regulates NK cell activity in vivo. Cell Immunol. 2003; 225: 122-130.

164. Yoneda O, Imai $\mathrm{T}$, Goda S, Inoue $\mathrm{H}$, Yamauchi A, Okazaki $\mathrm{T}$, et al. Fractalkine-mediated endothelial cell injury by NK cells. J Immunol. 2000; 164: 4055-4062.

165. Imaizumi $\mathrm{T}$, Yoshida $\mathrm{H}$, Satoh $\mathrm{K}$. Regulation of CX3CL1/fractalkine expression in endothelial cells. J Atheroscler Thromb. 2004; 11: 15-21.

166. Lee SJ, Namkoong S, Kim YM, Kim CK, Lee H, Ha KS, et al. Fractalkine stimulates angiogenesis by activating the Raf-1/MEK/ERK- and PI3K/Akt/eNOS-dependent signal pathways. Am J Physiol Heart Circ Physiol. 2006; 291: H2836-2846.

167. Brand S, Sakaguchi T, Gu X, Colgan SP, Reinecker HC. Fractalkine-mediated signals regulate cell-survival and immune-modulatory responses in intestinal epithelial cells. Gastroenterology. 2002; 122: 166-177.

168. Chandrasekar B, Mummidi S, Perla RP, Bysani S, Dulin NO, Liu F, et al. Fractalkine (CX3CL1) stimulated by nuclear factor kappaB (NF-kappaB)-dependent inflammatory signals induces aortic smooth muscle cell proliferation through an autocrine pathway. Biochem J. 2003; 373: 547-558.

169. Yao X, Qi L, Chen X, Du J, Zhang Z, Liu S. Expression of CX3CR1 associates with cellular migration, metastasis, and prognosis in human clear cell renal cell carcinoma. Urol Oncol. 2014; 32: 162-170.

170. Tardaguila M, Mira E, Garcia-Cabezas MA, Feijoo AM, Quintela-Fandino M, Azcoitia I, et al. CX3CL1 promotes breast cancer via transactivation of the EGF pathway. Cancer Res. 2013; 73: 4461-4473.

171. Tsang JY, Ni YB, Chan SK, Shao MM, Kwok YK, Chan KW, et al. CX3CL1 expression is associated with poor outcome in breast cancer patients. Breast Cancer Res Treat. 2013; 140: 495-504.

172. Park $\mathrm{MH}$, Lee JS, Yoon JH. High expression of CX3CL1 by tumor cells correlates with a good prognosis and increased tumor-infiltrating CD8+ T cells, natural killer cells, and dendritic cells in breast carcinoma. J Surg Oncol. 2012; 106: 386-392

173. Yu YR, Fong AM, Combadiere C, Gao JL, Murphy PM, Patel DD. Defective antitumor responses in CX3CR1-deficient mice. Int J Cancer. 2007; 121: 316-322.

174. Guo J, Zhang M, Wang B, Yuan Z, Guo Z, Chen T, et al. Fractalkine transgene induces T-cell-dependent antitumor immunity through chemoattraction and activation of dendritic cells. Int J Cancer. 2003; 103: 212-220.

175. Kee JY, Arita Y, Shinohara K, Ohashi Y, Sakurai H, Saiki I, et al. Antitumor immune activity by chemokine CX3CL1 in an orthotopic implantation of lung cancer model. Mol Clin Oncol. 2013; 1: 35-40.

176. Guo J, Chen T, Wang B, Zhang M, An H, Guo Z, et al. Chemoattraction, adhesion and activation of natural killer cells are involved in the antitumor immune response induced by fractalkine/CX3CL1. Immunol Lett. 2003; 89: $1-7$.

177. Schmall A, Al-Tamari HM, Herold S, Kampschulte M, Weigert A, Wietelmann A, et al. Macrophage and cancer cell cross-talk via CCR2 and CX3CR1 is a fundamental mechanism driving lung cancer. Am J Respir Crit Care Med. 2015; 191: 437-447.

178. Fox JC, Nakayama T, Tyler RC, Sander TL, Yoshie O, Volkman BF. Structural and agonist properties of XCL2, the other member of the C-chemokine subfamily. Cytokine. 2015; 71: 302-311.

179. Kelner GS, Kennedy J, Bacon KB, Kleyensteuber S, Largaespada DA, Jenkins NA, et al. Lymphotactin: a cytokine that represents a new class of chemokine. Science. 1994; 266: 1395-1399.

180. Hedrick JA, Saylor V, Figueroa $\mathrm{D}$, Mizoue $\mathrm{L}, \mathrm{Xu} \mathrm{Y}$, Menon $\mathrm{S}$, et al. Lymphotactin is produced by NK cells and attracts both NK cells and T cells in vivo. J Immunol. 1997; 158: 1533-1540.

181. Yoshida T, Imai $\mathrm{T}$, Kakizaki M, Nishimura $\mathrm{M}$, Takagi S, Yoshie $\mathrm{O}$. Identification of single C motif-1/lymphotactin receptor XCR1. J Biol Chem. 1998; 273: 16551-16554.

182. Luttichau HR, Johnsen AH, Jurlander J, Rosenkilde MM, Schwartz TW. Kaposi sarcoma-associated herpes virus targets the lymphotactin receptor with both a broad spectrum antagonist vCCL2 and a highly selective and potent agonist vCCL3. J Biol Chem. 2007; 282: 17794-17805.

183. Kim M, Rooper L, Xie J, Rayahin J, Burdette JE, Kajdacsy-Balla AA, et al. The lymphotactin receptor is expressed in epithelial ovarian carcinoma and contributes to cell migration and proliferation. Mol Cancer Res. 2012; 10: 1419-1429.
184. Zhang W, He L, Cao X. [Enhanced antitumor effects induced by lymphotactin gene-modified dendritic cells after pulsed with tumor antigen peptide]. Zhonghua Yi Xue Za Zhi. 1999; 79: 170-173.

185. Cairns CM, Gordon JR, Li F, Baca-Estrada ME, Moyana T, Xiang J. Lymphotactin expression by engineered myeloma cells drives tumor regression: mediation by $\mathrm{CD} 4+$ and $\mathrm{CD} 8+\mathrm{T}$ cells and neutrophils expressing XCR1 receptor. J Immunol. 2001; 167: 57-65.

186. Wu FY, Ou ZL, Feng LY, Luo JM, Wang LP, Shen ZZ, et al. Chemokine decoy receptor d6 plays a negative role in human breast cancer. Mol Cancer Res. 2008; 6: 1276-1288.

187. Harata-Lee Y, Turvey ME, Brazzatti JA, Gregor CE, Brown MP, Smyth MJ, et al. The atypical chemokine receptor CCX-CKR regulates metastasis of mammary carcinoma via an effect on EMT. Immunol Cell Biol. 2014; 92: 815-824

188. Wu FY, Fan J, Tang L, Zhao YM, Zhou CC. Atypical chemokine receptor D6 inhibits human non-small cell lung cancer growth by sequestration of chemokines. Oncol Lett. 2013; 6: 91-95. 